OPEN ACCESS

Edited by:

Dong Zhou,

University of Connecticut,

United States

Reviewed by:

Yanjiao Zhou,

UCONN Health, United States

Yue Tu,

Nanjing University of Chinese

Medicine, China

Minggang Wei,

The First Affiliated Hospital of

Soochow University, China

*Correspondence: Souhaila Al Khodor salkhodor@sidra.org

Specialty section:

This article was submitted to Nephrology

a section of the journal

Frontiers in Medicine

Received: 07 October 2021 Accepted: 20 December 2021 Published: 17 January 2022

Citation:

Wehedy E, Shatat IF and Al Khodor S (2022) The Human Microbiome in Chronic Kidney Disease: A Double-Edged Sword

Front. Med. 8:790783. doi: 10.3389/fmed.2021.790783

\section{The Human Microbiome in Chronic Kidney Disease: A Double-Edged Sword}

\author{
Eman Wehedy ${ }^{1,2}$, Ibrahim F. Shatat ${ }^{3}$ and Souhaila Al Khodor ${ }^{1,2 *}$ \\ ${ }^{1}$ College of Health and Life Sciences, Hamad Bin Khalifa University, Doha, Qatar, ${ }^{2}$ Research Department, Sidra Medicine, \\ Doha, Qatar, ${ }^{3}$ Nephrology Department, Sidra Medicine, Doha, Qatar
}

Chronic kidney disease (CKD) is an increasing global health burden. Current treatments for CKD include therapeutics to target factors that contribute to CKD progression, including renin-angiotensin-aldosterone system inhibitors, and drugs to control blood pressure and proteinuria control. Recently, associations between chronic disease processes and the human microbiota and its metabolites have been demonstrated. Dysbiosis - a change in the microbial diversity - has been observed in patients with CKD. The relationship between CKD and dysbiosis is bidirectional; gut-derived metabolites and toxins affect the progression of CKD, and the uremic milieu affects the microbiota. The accumulation of microbial metabolites and toxins is linked to the loss of kidney functions and increased mortality risk, yet renoprotective metabolites such as shortchain fatty acids and bile acids help restore kidney functions and increase the survival rate in CKD patients. Specific dietary interventions to alter the gut microbiome could improve clinical outcomes in patients with CKD. Low-protein and high-fiber diets increase the abundance of bacteria that produce short-chain fatty acids and anti-inflammatory bacteria. Fluctuations in the urinary microbiome are linked to increased susceptibility to infection and antibiotic resistance. In this review, we describe the potential role of the gut, urinary and blood microbiome in CKD pathophysiology and assess the feasibility of modulating the gut microbiota as a therapeutic tool for treating CKD.

Keywords: chronic kidney disease, gut microbiota, urinary microbiome, dysbiosis, uremic toxins, renoprotective, diet therapy

\section{INTRODUCTION}

Chronic kidney disease (CKD) is a growing healthcare burden affecting about $13.4 \%$ of the population worldwide (1). In the last few decades, the number of CKD patients has steadily increased (2). In adults, hypertension and diabetes are the leading causes of CKD, while congenital anomalies of the kidney and urogenital track account for the majority of CKD etiologies in children. Factors that contribute to the progression of CKD include activation of the renin-angiotensinaldosterone system, proteinuria, a state of chronic inflammation and repetitive acute kidney injury (3-7). CKD is associated with the development of severe health conditions like cardiovascular diseases, neurological complications, adverse pregnancy outcomes, and hyperkalemia (8-12). In children, CKD affects neurocognitive abilities, school performance, growth, quality of life and the cost of medical care $(6,13-15)$. 
Current treatments for CKD include renin-angiotensinaldosterone system inhibitors and drugs to control blood pressure and proteinuria. An increasing number of studies suggest that the composition of the microbiome has a key role in maintaining health. The human microbiome is the collection of all microbial DNA in the human body, which is distributed in various body parts as; skin, gastrointestinal, urinary tract, respiratory tract, and oral cavity (16). These microbes play crucial roles in the digestion and metabolic processes, stimulation and regulation of the immune response, production of vitamins, and protection against pathogens $(17,18)$. This microbial community is in a symbiotic relation with the host in the healthy states (19). Dysbiosis refers to a disruption of the microbial balance, and this phenomenon is associated with various diseases and pathological conditions including $\operatorname{CKD}(20,21)$.

The major part of the human microbiome is centralized in the gut (22). The gut microbiota harbors 10-fold more microbial cells than human cells, which regulates nutrient metabolism and produces various metabolites that affect the kidney, heart, vascular system, and liver (23). There is a bi-directional relationship between dysbiosis and the pathogenesis of $\mathrm{CKD}$ (20, 24-26). We summarized this relationship in Figure 1. It is well-established that an increase in levels of harmful metabolites including trimethylamine $\mathrm{N}$-oxide (TAMO), indoxyl sulfate, and $p$-cresyl sulfate are associated with renal fibrosis, endothelial dysfunction, a decline in the estimated glomerular filtration rate (eGFR), cardiovascular complications, and increased mortality and morbidity in CKD (27-30). Moreover, the serum levels of 5-methoxytryptophan and indoxyl sulfate correlate positively with CKD progression (31). On the other hand, renoprotective metabolites including short-chain fatty acids prevent the progression of CKD by suppressing the disruption of the epithelial barrier and regulating the antiinflammatory response $(25,32)$. The level of indole propionic acid, derived from the gut flora, negatively correlates with p-cresyl sulfate and indoxyl sulfate concentrations in CKD patients (33).

The composition of the gut microbiota can be altered by therapeutic dietary interventions and intake of probiotics, and so dietary interventions and probiotics intake can be used to improve CKD outcomes $(27,34)$. A very low-protein diet decreases plasma levels of indoxyl sulfate, and $p$-cresyl sulfate and increases the diversity of both butyrate-forming bacteria such as Coprococcus and Roseburia, and the levels of antiinflammatory bacteria like Blautia and Faecalibacterium (27). A high-fiber diet improves kidney function by lowering the harmful uremic metabolite levels and decreasing microbial diversity (35). Conversely, a high-fat diet increases the plasma level of gut microbiota-derived TAMO metabolites in a mouse model (36).

While the gut is the main repertoire of microbes and the most studied site to date, urine and blood also harbor different types of microbes and microbial signatures in both healthy and disease

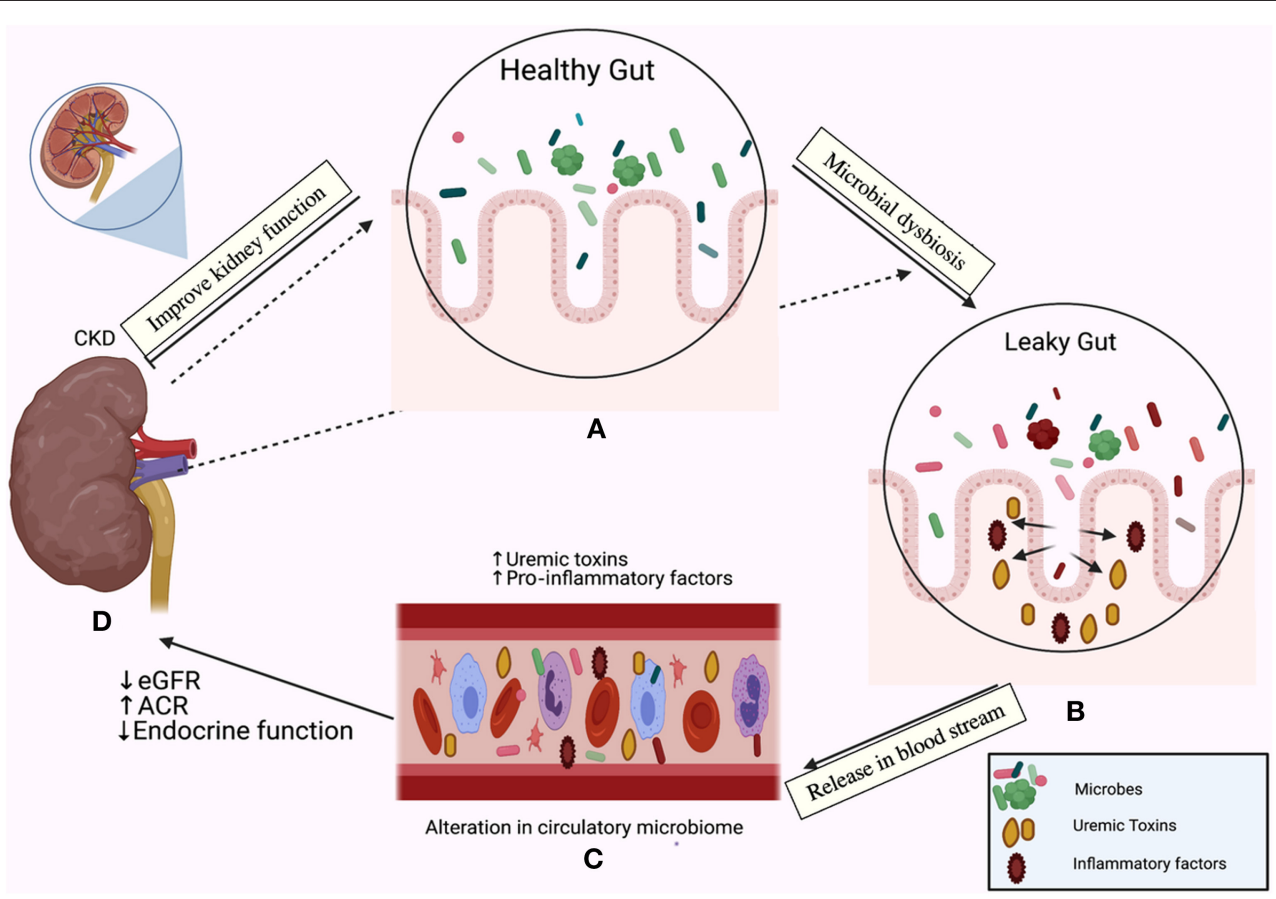

FIGURE 1 | The relationship between the gut microbiome and chronic kidney disease (CKD) is bi-directional. In one direction, the gut microbiota affect the kidney; the emerging role of gut microbiota in (A) The healthy gut, (B) The leaky gut due to microbial dysbiosis and disruption of the mucosal layer, (C) Release of pro-inflammatory factors in the bloodstream and initiation of the inflammatory cascade, accumulation of uremic toxins, (D) A decline in the estimated glomerular filtration rate (eGFR), the elevation of the albumin creatinine ratio (ACR) and loss of the endocrine functions of the kidney. In the other direction, CKD drives dysbiosis in the gut (indicated by the dotted arrows) and initiates an inflammatory cascade. 
TABLE 1 | Role of gut microbiota and microbial related metabolites in the pathogenesis of CKD (Clinical studies).

\begin{tabular}{|c|c|c|c|c|}
\hline CKD model & $\begin{array}{l}\text { Microbial related } \\
\text { metabolite (s) }\end{array}$ & Main findings & Technique(s) & Study \\
\hline $\begin{array}{l}52 \text { ESRD patients and } \\
44 \text { healthy controls }\end{array}$ & $\begin{array}{l}\text { Pseudouridine, } \\
\text { I-phenylalanine, } \\
\text { and p-hydroxyphenylacetic } \\
\text { acid. }\end{array}$ & $\begin{array}{l}\text { 1. I-phenylalanine and } \\
\text { p-hydroxyphenylacetic acid levels are } \\
\text { positively correlated with CRP levels } \\
\text { in ESRD and healthy controls groups } \\
\text { 2. In ESRD patients, pseudouridine, } \\
\text { I-phenylalanine, and p-hydroxyphenyl } \\
\text { acetic acid metabolites positively } \\
\text { correlated with IL-6 levels. } \\
\text { 3. Inflammatory markers and } \\
\text { metabolites can be used a diagnostic } \\
\text { and predictive marker for CKD. }\end{array}$ & LC/MS & (40) \\
\hline $\begin{array}{l}\text { *223 patients with ESRD } \\
\text { and } 69 \text { healthy controls. }\end{array}$ & $\begin{array}{l}\text { PCS } \\
\text { IS } \\
\text { Phenylacetylglycine } \\
\text { phenyl sulphate }\end{array}$ & $\begin{array}{l}\text { 1. Alteration in gut microbiota in CKD } \\
\text { Patients; increased the abundance of } \\
\text { Eggerthella lenta, Flavonifractor spp, } \\
\text { Alistipes spp, Ruminococcus spp } \\
\text { and Fusobacterium spp, and } \\
\text { depleted Prevotella spp, Clostridium } \\
\text { spp, SCFA-producing species and } \\
\text { several butyrate producers } \\
\text { (Roseburia spp, Faecalibacterium } \\
\text { prausnitzii and Eubacterium rectale). } \\
\text { 2. Aberrant gut microbiota and its } \\
\text { derived uremic toxins are associated } \\
\text { with disease development. }\end{array}$ & $\begin{array}{l}\text { Shot gun } \\
\text { metagenome } \\
\text { sequencing and } \\
\text { HPLC }\end{array}$ & (39) \\
\hline $\begin{array}{l}\text { *30 Caucasian CKD } \\
\text { patients (stage 3), } 121 \\
\text { Caucasian CKD patients } \\
\text { (stage 5), and } 80 \\
\text { controls }\end{array}$ & $\begin{array}{l}\text { Betaine, choline, and } \\
\text { TMAO }\end{array}$ & $\begin{array}{l}\text { 1. Advanced CKD patients (stage 5) } \\
\text { expressed the lowest level of } \\
\text { circulating betaine and highest levels } \\
\text { of choline and TMAO compared with } \\
\text { CKD patients (stage 3) and } \\
\text { healthy controls. } \\
\text { Serum betaine levels significantly } \\
\text { declined with renal function drop. }\end{array}$ & LS-MS & (41) \\
\hline $\begin{array}{l}141 \text { CKD patients and } \\
14 \text { controls. }\end{array}$ & $\begin{array}{l}\text { PCS, IS, p-cresyl } \\
\text { glucuronide, and } \\
\text { Indole-3-acetic acid. }\end{array}$ & $\begin{array}{l}\text { 1. Increasing the plasma level of } \\
\text { gut-derived uremic toxins is } \\
\text { associated with impaired kidney } \\
\text { functions and decline in eGFR. } \\
\text { The clearance of plasma } \\
\text { protein-bounded metabolites is } \\
\text { decreased with disease progression. }\end{array}$ & HPLC & (28) \\
\hline $\begin{array}{l}77 \text { CKD patients } \\
\text { undergoing } \\
\text { hemodialysis and } 30 \\
\text { healthy }\end{array}$ & Putrescine & $\begin{array}{l}\text { 1. Hemodialysis patients with mild } \\
\text { cognitive decline showed a significant } \\
\text { reduction in Class Coriobacteriia and } \\
\text { genus Tyzzerella 3, Blautia, } \\
\text { and Lachnospira } \\
\text { 2. Bilophila, and serum putrescine } \\
\text { (gut-related metabolite) can be a } \\
\text { sensitive marker for cognitive decline } \\
\text { in hemodialysis patients. }\end{array}$ & $\begin{array}{l}16 S \text { rRNA gene } \\
\text { sequencing and } \\
\text { GC-MS }\end{array}$ & (43) \\
\hline
\end{tabular}


TABLE 1 | Continued

\begin{tabular}{ll}
\hline CKD model & $\begin{array}{l}\text { Microbial related } \\
\text { metabolite (s) }\end{array}$ \\
\hline 72 patients with CKD & $\begin{array}{l}\text { PCS, Secondary bile acid, } \\
\text { and ipopolysaccharide } \\
\text { biosynthes. }\end{array}$
\end{tabular}

115 children and adolescents with CKD stage (1-4)

92 adult CKD patients (31 mild, 30 moderate, and 31 advanced) and 30 healthy controls

Phase1: 10 patients with rapid decline in eGFR and 10 control patients without rapid decline Phase 2: 140 CKD and 144 healthy controls

95 CKD patient with differed stages, 11 hemodialysis patients, and 18 healthy controls Trimethylamine

IS and PCS

Indole propionic acid, IS PCS
Main findings

Technique(s)

Study

1. The early stages of CKD showed a high abundance of secondary bile acid biosynthesis microbial genes, but lipid metabolism and lipopolysaccharide biosynthesis are enriched in the advanced stages.

1. Bacteroides eggerthii can be a biomarker for the early stages of the disease.

2. CKD group showed a low abundance of Prevotella sp. 885.

3. PCS is negatively correlated with the eGFR.

TMAO, dimethylamine, and

1. Gut related metabolites are associated with blood pressure abnormalities and cardiovascular risk in pediatric CKD.

2. Decrease in the diversity of Phylum Cyanobacteria, genera Subdoligranulum, Faecalibacterium, Ruminococcus, and Akkermansia in CKD patients with abnormal blood pressure.

3. Plasma levels of dimethylamine, and trimethylamine are inversely associated eGFR.

Accumulation of TAMO, dimethylamine, and trimethylamine are higher in advanced CKD.

1. Accumulation of uremic toxins IS and PCS are positively correlated with disease progression.

2. The diversity of gut microbiota (genus-level: Escherichia_Shigella, Dialister,

Lachnospiraceae_ND3007_group, Pseudobutyrivibrio, Roseburia, Paraprevotella and Ruminiclostridium, and species-level: Collinsella stercoris and Bacteroides eggerthii) are highly associated with CKD stages.

1. Indole propionic acid produced from a healthy gut is highly reduced in CKD patients and patients with a decline in eGFR.

2. Indole propionic acid (renal protective metabolite) can be a biomarker for renal function.

3. IS and PCS were high in the CKD group compared with controls

1. CKD patients have a high level of TMAO.

Plasma TMAO is inversely correlated with eGFR.
Shotgun

sequencing and

Metabolomics

(GC-MS)

16S rRNA gene sequencing and LC-MS/MS

(24)

16S rRNA gene sequencing

(20)

HPLC

LC-MS/MS 
TABLE 1 | Continued

\begin{tabular}{|c|c|c|c|c|}
\hline CKD model & $\begin{array}{l}\text { Microbial related } \\
\text { metabolite (s) }\end{array}$ & Main findings & Technique(s) & Study \\
\hline $\begin{array}{l}78 \text { children and } \\
\text { adolescents with CKD } \\
\text { stage G1 to G4 }\end{array}$ & $\begin{array}{l}\text { Short chain fatty acids, } \\
\text { propionate, and butyrate }\end{array}$ & $\begin{array}{l}\text { 1. CKD children with congenital } \\
\text { anomalies of the kidney and urinary } \\
\text { tract (CAKUT) showed a reduction I } \\
\text { plasma level of propionate with } \\
\text { increase in the relative abundance of } \\
\text { phylum Verrucomicrobia, genus } \\
\text { Akkermansia, and species } \\
\text { Bifidobacterium bifidum. } \\
\text { 2. The Firmicutes to Bacteroidetes ratio } \\
\text { didn't show significant difference } \\
\text { between groups. } \\
\text { CKD children with an abnormal } \\
\text { ambulatory blood-pressure monitoring } \\
\text { profile had higher plasma levels of } \\
\text { propionate and butyrate. }\end{array}$ & $\begin{array}{l}\text { 16S rRNA gene } \\
\text { sequencing \& } \\
\text { GC-Flame } \\
\text { lonization detector }\end{array}$ & (45) \\
\hline $\begin{array}{l}86 \text { CKD children stage } \\
(1-3)\end{array}$ & Urinary TMAO & $\begin{array}{l}\text { 1. Urinary TMAO is positively correlate } \\
\text { with Bifidobacterium, Lactobacillus, } \\
\text { Collinsella and Blautia. } \\
\text { 2. CKD children with abnormal } \\
\text { ambulatory blood-pressure } \\
\text { monitoring (ABPM) profile had a } \\
\text { lower abundance of the Prevotella } \\
\text { genus than those with normal ABPM }\end{array}$ & $\begin{array}{l}\text { LC-MS and 16S } \\
\text { rRNA gene } \\
\text { sequencing }\end{array}$ & $(47)$ \\
\hline $\begin{array}{l}488 \text { CKD patients } \\
\text { (stages 1-5) }\end{array}$ & phenylacetylglutamine & $\begin{array}{l}\text { 1. Phenylacetylglutamine is highly } \\
\text { accumulated in advanced stages } \\
\text { of CKD. } \\
\text { 2. Elevation of serum level of } \\
\text { phenylacetylglutamine is a risk factor } \\
\text { for cardiovascular disease high } \\
\text { mortality rate in CKD patients. }\end{array}$ & LC-MS & (50) \\
\hline $\begin{array}{l}51 \text { renal transplant } \\
\text { recipients, } 51 \text { CKD } \\
\text { patients, and } 65 \text { stable } \\
\text { renal transplant } \\
\text { recipients (unrelated } \\
\text { cohort) }\end{array}$ & $\begin{array}{l}\text { PCS, IS, TMAO, p-cresyl } \\
\text { glucuronide, and } \\
\text { Phenylacetylglutamine }\end{array}$ & $\begin{array}{l}\text { 1. The serum levels of gut-derived } \\
\text { uremic toxins are significantly } \\
\text { decreased after renal transplantation } \\
\text { compared with CKD patients. }\end{array}$ & UPLC-MS/MS & (51) \\
\hline
\end{tabular}


TABLE 1 | Continued

\begin{tabular}{|c|c|c|c|c|}
\hline CKD model & $\begin{array}{l}\text { Microbial related } \\
\text { metabolite (s) }\end{array}$ & Main findings & Technique(s) & Study \\
\hline $\begin{array}{l}227 \text { CKD patients (had } \\
\text { cardiovascular surgery } \\
\text { for coronary artery } \\
\text { disease) }\end{array}$ & TMAO & $\begin{array}{l}\text { 1. The advanced stage of CKD showed } \\
\text { the highest TMAO level. } \\
\text { 2. The elevated level of TMAO is } \\
\text { associated with CKD development } \\
\text { and infracted coronary arteries. }\end{array}$ & $\begin{array}{l}\text { HPLC-APCl- } \\
\text { MS/MS }\end{array}$ & (52) \\
\hline $\begin{array}{l}{ }^{*} 521 \text { stable subjects } \\
\text { with CKD }\end{array}$ & TAMO & $\begin{array}{l}\text { 1. TAMO is associated with the } \\
\text { progression of renal dysfunction, } \\
\text { poor prognosis, and mortality risk in } \\
\text { CKD patients. } \\
\text { 2. Elevated TMAO is a risk factor for } \\
\text { cardiovascular disease. }\end{array}$ & LC/MS/MS & (54) \\
\hline
\end{tabular}

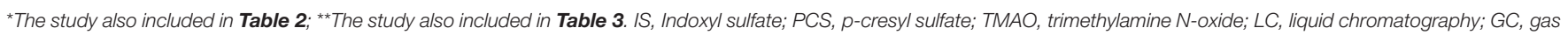

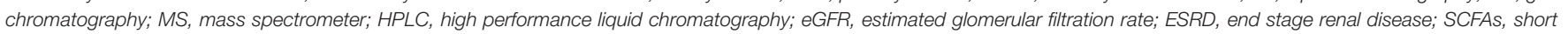
chain fatty acids; NMR, nuclear magnetic resonance.

conditions $(22,37,38)$. Several studies have examined the role of gut-derived metabolites in $\mathrm{CKD}$, but little is known about the role of the composition of the urinary and blood microbiomes in the progression of CKD $(20,28,39)$.

Our manuscript will focus on the relationship between the human microbiome and its products in the CKD pathophysiology and modulating the gut microbiota as a therapeutic strategy for CKD treatment.

\section{PATHOPHYSIOLOGY OF CKD}

A medical literature search was conducted using PubMed for articles published until May $24^{\text {th }}, 2021$. The initial search was done using the general search terms: "microbiome," "chronic kidney disease," and "metabolites." Only articles published in English were included. The search resulted in a total of 143 articles. After excluding review articles, we focused on 57 studies summarized in Tables 1, 2, 3, we classified the studies based on the CKD model into clinical studies, animal studies, and dietary interventions studies. References of the included articles were also reviewed for additional relevant articles.

To sum up three studies were included in the clinical (Table 1) and animal (Table 2) studies, and one study was included in Tables 1, 3 as different CKD models have been used in these four studies. In the tables, we focused on the techniques used to assess gut microbiota and microbial related metabolites not all the techniques used in each study. Of note, gut microbiota and its related metabolites have a significant role in CKD progression and are associated with different circumstances. The exact mechanism of the gut-kidney axis is not clearly identified and both mechanisms of the role of gut microbiota in CKD (causative or consequence) are applicable. Furthermore, dietary intervention studies using animal models showed a change in the disease outcomes, but in humans did not show a big difference. This may be due to most of the participants were in a late CKD stage (ESRD or CKD on hemodialysis) in which most kidney functions are compromised.

CKD encompasses a spectrum of pathophysiologic processes associated with abnormal kidney function and a progressive decline in the glomerular filtration rate (GFR) (29). The underlying etiology varies by age, presence of co-morbid conditions, repeated occurrences of acute kidney injury and level of proteinuria $(5,6)$. The decline in kidney function and micro-structural changes are considered chronic when they last more than 3 months (85). Irrespective of the underlying etiology (which is considered the initiating mechanism), hyperfiltration and hypertrophy of the remaining nephrons, tubulointerstitial fibrosis, activation of the renin-angiotensin-aldosterone system, and disruption of endothelial barriers disruption are common and lead to a reduction in the renal excretion efficacy and decline in the eGFR $(3,86)$. The eGFR is used to grade disease severity in CKD patients, a higher grade is associated with a lower filtration rate and more advanced disease (85). The transition from one grade to the next grade is usually accompanied by a loss in the endocrine function of the kidney (86). In particular, CKD patients suffering from cardiovascular events show deterioration in renal functions and severe inflammation (87). Infiltration of immune cells in the tubulointerstitial space and accumulation of immune-derived components contribute to CKD progression (88). A key goal of $\mathrm{CKD}$ therapies is to prevent patients progressing to the next stage of the disease. 
TABLE 2 | Role of gut microbiota and microbial related metabolites in the pathogenesis of CKD (Animal models studies).

\begin{tabular}{|c|c|c|c|c|}
\hline CKD Model & $\begin{array}{l}\text { Microbial related } \\
\text { metabolite (S) }\end{array}$ & Main findings & Technique(s) & Study \\
\hline $\begin{array}{l}\text { Organic anion } \\
\text { transporter } 1 \text { (Oat1) } \\
\text { knockout mice and wild } \\
\text { type }\end{array}$ & $\begin{array}{l}\text { IS, kynurenine, and } \\
\text { xanthurenic acid }\end{array}$ & $\begin{array}{l}\text { 1. Oat1 knockout mice expressed } \\
\text { accumulation of IS, kynurenine, and } \\
\text { xanthurenic acid metabolites. } \\
\text { 2. There is a remote link between gut } \\
\text { microbiota, phase II metabolism in } \\
\text { the liver and the elimination of uremic } \\
\text { toxins in the kidney through Oat1. }\end{array}$ & LC-MS/MS & (55) \\
\hline $\begin{array}{l}\text { Male C57BL/6 mice with } \\
\text { unilateral nephrectomy }\end{array}$ & IS & $\begin{array}{l}\text { 1. Accumulation of circulatory uremic } \\
\text { toxin (IS) was associated with } \\
\text { neurological complications and } \\
\text { increased oxidative stress in the } \\
\text { CKD mice model. } \\
\text { 2. Applying AST-120 (Uremic toxin } \\
\text { adsorbent) reversed the effects of IS. } \\
\text { 3. Gut microbiota is a potential target } \\
\text { to control CKD progression and its } \\
\text { related circumstances. }\end{array}$ & HPLC & (56) \\
\hline $\begin{array}{l}\text { Male C57/BL6 mice } \\
\text { (Unilateral ureteral } \\
\text { obstruction and sham } \\
\text { control) }\end{array}$ & $\begin{array}{l}\text { Myo-inositol, } \\
\text { dodecanoic acid, } \\
\text { N-acetylputrescine, } \\
\text { and anthranilic acid. }\end{array}$ & $\begin{array}{l}\text { 1. CKD mice group showed a } \\
\text { reduction in short-chain fatty } \\
\text { acids-producing genera } \\
\text { (Bacteroides, } \\
\text { Prevotellaceae_UCG-001, } \\
\text { Roseburia, and } \\
\text { Lachnospiraceae_NK4A136_group). } \\
\text { 2. Bacteroides and } \\
\text { Prevotellaceae_UCG-001were } \\
\text { negatively associated with renal } \\
\text { fibrosis. } \\
\text { 3. Parasutterella and Alistipes were } \\
\text { positively correlated with CKD } \\
\text { progression. } \\
\text { 4. Myo-inositol, dodecanoic acid, } \\
\text { N-acetylputrescine, and Anthranilic } \\
\text { acid were positively correlated with } \\
\text { renal damage. }\end{array}$ & $\begin{array}{l}\text { 16S rRNA gene } \\
\text { sequencing and } \\
\text { LC-MS }\end{array}$ & (57) \\
\hline $\begin{array}{l}\text { Female Sprague-Dawley } \\
\text { rats (Maternal CKD } \\
\text { model) }\end{array}$ & TAMO \& SCFAs & $\begin{array}{l}\text { 1. CKD Rats showed a high } \\
\text { accumulation of TAMO, reduction in } \\
\text { SCFAs (acetate, butyrate), and } \\
\text { dysregulation of the } \\
\text { renin-angiotensin system. } \\
\text { 2. CKD group expressed a higher } \\
\text { Firmicutes to Bacteroidetes ratio } \\
\text { compared to the controls group. } \\
\text { 3. Phylum Bacteroidetes was low } \\
\text { abundance in the CKD group. } \\
\text { Maternal CKD is associated with } \\
\text { hypertension and renal damage in } \\
\text { the adult male offspring. }\end{array}$ & $\begin{array}{l}\text { 16s rRNA gene } \\
\text { sequencing and } \\
\text { LC-MS }\end{array}$ & (58) \\
\hline
\end{tabular}


TABLE 2 | Continued

CKD Model
Male IQI, C57BL/6Njc1,
and C57BL/6JJcl mice

* Germ free
adenine-induced CKD
mice (transplanted with
fresh gut microbiota
from ESRD patients and
healthy controls. \& $5 / 6$
nephrectomy CKD rat.

Subtotal nephrectomy rat model

5/6 nephrectomized (NX) rat model and sham controls.

Germ free and specific pathogen free IQI Mice

Male Sprague-Dawley rats (Unilateral ureteral obstruction (UUO) and sham operating control)

\section{Microbial related}

metabolite (S)

Purine, Allantoin, and purine

PCS,

phenylacetylglycine, phenyl sulphate, and IS

Gut

microbiome-derived uremic solutes

Glycine-conjugated compounds and polyamine metabolites.

SCFAs, Indole-3-acetic acid, and n-3 type of polyunsaturated fatty acid

Tryptophan related metabolites (kynurenine, 5-hydroxytryptophan and

5-hydroxytryptamine)
Main findings

Technique(s)

Study

1. Germ-free mice showed renal damage and inflammatory responses with high expression of purine metabolizing enzymes.

2. Purine metabolizing enzymes are responsible for converting adenine to a nephrotoxic byproduct 2,8-dihydroxyadenine.

1. PCS, phenylacetylglycine, phenyl sulphate and IS, were significantly increased in mice that received ESRD microbiota.

2. Aberrant gut microbiota is responsible for renal disease development.

3. High abundance of Eggerthella lenta and Fusobacterium nucleatum species in CKD model, but gavage the rat with Bifidobacterium animalis A6 decreased their abundance.

1. There is a complex communication between gut, kidney, blood, and liver controlling uremic toxin retention.

2. Organic anion transporters (OATs) are essential to evaluate plasma uremic toxins levels.

1. CKD rats expressed a high abundance of Allobaculum, Escherichia_Shigella,

Clostridium_sensu_stricto, Bacteroides, Parasutterella, Ruminococcus, Blautia and Enterorhabdus.

2. Blautia was positively correlated with proteinuria.

3. The creatinine clearance rate is affected by gut flora and polyamine metabolism.

1. Gut-derived metabolites (SCFAs) have a preventive role in the disruption of endothelial barriers. Germ-free mice expressed significantly low SCFAs with renal failure.

1. Plasma levels of tryptophan-related metabolites were high in the UUO group and showed a positive association with tubulointerstitial fibrosis.

2. UUO changed the abundance of some gut microbiota (reduction and enrichment).

3. Clostridium IV, Turicibacter, Pseudomonas, and Lactobacillales were positively correlated with plasma tryptophan level, while Oscillibacter, Blautia, and Intestinimonas showed a negative correlation.
16S rRNA gene sequencing and HPLC

UPLC-MS

1.16S rRNA gene sequencing and UPLC-MS

LC-MS/MS

16S rRNA gene sequencing and UPLC-MS
(59)

(Continued) 
TABLE 2 | Continued

\begin{tabular}{|c|c|c|c|c|}
\hline CKD Model & $\begin{array}{l}\text { Microbial related } \\
\text { metabolite (S) }\end{array}$ & Main findings & Technique(s) & Study \\
\hline $\begin{array}{l}\text { Chronic nephropathy } \\
\text { rats and controls rats }\end{array}$ & $\begin{array}{l}\text { Hydrogenated and } \\
\text { demethylated } \\
\text { loganetin, } \\
\text { demethylated } \\
\text { morronisid aglycone } \\
\text { and dehydroxylated } \\
\text { morronisid aglycone }\end{array}$ & $\begin{array}{l}\text { 1. The gut microflora of healthy rats is } \\
\text { more efficient in degrading loganin } \\
\text { and morronisid than that of } \\
\text { nephropathy rats. }\end{array}$ & UPLC-Q-TOF/MS & (63) \\
\hline $\begin{array}{l}\text { Adenine-induced renal } \\
\text { failure and control mice } \\
\text { (with germ-free or } \\
\text { specific pathogen-free } \\
\text { conditions) }\end{array}$ & $\begin{array}{l}\text { Uremic toxins as (IS, } \\
\text { PCS, TAMO, choline) \& } \\
\text { SCFAs }\end{array}$ & $\begin{array}{l}\text { 1. Gut microbiota has a dual role in } \\
\text { CKD, it is responsible for the } \\
\text { accumulation of uremic toxins, but } \\
\text { the germ-free mice model showed } \\
\text { severe renal damage. } \\
\text { 2. Shortage of SCFAs and reduction in } \\
\text { amino acid metabolism were higher } \\
\text { in germ-free mice than specific } \\
\text { pathogen-free mice. }\end{array}$ & CE-TOF/MS & (26) \\
\hline $\begin{array}{l}\text { *Wistar rats } 5 / 6 \text { th } \\
\text { nephrectomy and sham } \\
\text { operated control rats }\end{array}$ & $\begin{array}{l}\text { p-cresol and indole } \\
\text { (precursors of PCS and } \\
\text { IS) }\end{array}$ & $\begin{array}{l}\text { 1. Accumulation of uremic toxins are } \\
\text { higher in CKD group than in control } \\
\text { group. } \\
\text { 2. Gut-derived metabolites (IS and } \\
\text { PCS) are associated with CKD } \\
\text { progression, cardiovascular disease } \\
\text { risk, and overall mortality. }\end{array}$ & GC-MS & (53) \\
\hline
\end{tabular}

*The study also included in Table 1, IS, Indoxyl sulfate; PCS, p-cresyl sulfate; TMAO, trimethylamine N-oxide; CE-TOF/MS, capillary electrophoresis time-of-flight mass spectrometrybased approach; HPLC, high performance liquid chromatography; LC, liquid chromatography; GC, gas chromatography; MS, mass spectrometer; LC, liquid chromatography; GC, gas chromatography; MS, mass spectrometer; HPLC, high performance liquid chromatography; eGFR, estimated glomerular filtration rate; ESRD, End stage renal disease; SCFAs, short chain fatty acids; UPLC, ultraperformance liquid chromatography.

\section{MICROBIAL DYSBIOSIS IN CKD}

The dominant bacterial phyla in the gut are Firmicutes, Bacteroidetes, Actinobacteria, and Proteobacteria (89). The interplay between bacteria present in the gut (and their metabolites) and kidney function is occasionally referred to as the gut-kidney axis (90). Recent studies indicate that aberrant gut microbiota has a key role in the pathophysiology of CKD with severe CKD outcomes $(24,61)$. Bifidobacterium and Lactobacilli are negatively correlated with CKD progression and long-term survival $(27,34,39)$. A study of 223 patients with end-stage renal disease revealed that Eggerthella lenta, Fusobacterium nucleatum, and Alistipes shahii are positively correlated with increased levels of secondary bile acids and uremic toxins in CKD patients compared with the control group (39). In this study, the authors showed that the presence of Faecalibacterium prausnitzii,
Roseburia, and Prevotella (which produce short-chain fatty acids) was negatively correlated with disease progression and uremic toxin accumulation (39). Another study of 92 patients with CKD reported an increased abundance of Paraprevotella, Pseudobutyrivibrio, and Collinsella stercoris in the CKD cohort; this finding led the authors to suggest that this signature can be used to discriminate between patients with CKD (even those in the early stages of the disease) and healthy individuals (20).

Dysbiosis in the gut has an emerging role in many inflammatory-related diseases and is thought to contribute to the inflammatory component of both acute and chronic kidney disease $(91,92)$. Microbial alterations in the gut affects the permeability of the intestinal mucosal barrier and releases proinflammatory factors and endotoxins in the bloodstream, which initiate the inflammatory cascade (93). 
TABLE 3 | Effect of dietary intervention on CKD outcomes.

\begin{tabular}{|c|c|c|c|c|c|}
\hline CKD model & Dietary regimen & $\begin{array}{l}\text { Microbial related } \\
\text { metabolite (s) }\end{array}$ & Main findings & Technique(s) & Study \\
\hline $\begin{array}{l}\text { C57BL/6J male mice } \\
\text { NPX or sham } \\
\text { operation and } \\
\text { ApoE }^{-/-} \text {mice } \\
\text { (B6.129P2- } \\
\text { Apoe }^{\text {tm1Unc/J) }}\end{array}$ & $\begin{array}{l}\text { Three groups for } 2 \text { weeks } \\
\text { Group 1: High fat diet (HFD) + } \\
\text { Vehicle } \\
\text { Group 2: HFD + } \\
\text { unconjugated p-cresol (UPC) } \\
\text { Group 3: HFD + PCS } \\
\text { Fecal transplantation } \\
\text { ApoE- } /- \text { mice fed with HFD and } \\
\text { fecal transplantation from CKD } \\
\text { mice and Sham Control Mice for } \\
19 \text { weeks ( } 3 \text { times a week). }\end{array}$ & $\begin{array}{l}\text { Unconjugated } \\
\text { p-cresol (UPC) and } \\
\text { PCS }\end{array}$ & $\begin{array}{l}\text { 1. Mice fed with HFD and had fecal } \\
\text { transplantation showed increased } \\
\text { coronary artery lipids deposits. } \\
\text { 2. Non-CKD mice treated with uPC } \\
\text { expressed a higher level of total } \\
\text { cholesterol, and triglycerides, } \\
\text { apoptosis. } \\
\text { 3. Mice fed a high-fat diet } \\
\text { (atherosclerosis) develop higher } \\
\text { coronary artery lipid deposits after } \\
\text { receiving fecal material from } \\
\text { CKD mice. }\end{array}$ & LC-MS & (66) \\
\hline $\begin{array}{l}\text { Male Sprague-Dawley } \\
\text { (SD) rats }\end{array}$ & $\begin{array}{l}\text { Six groups ( } 4 \text { weeks intervention) } \\
\mathrm{N} \text { group (normal rats) } \\
\mathrm{M} \text { group (CKD rats) } \\
\text { HK group (Huangkui capsule } \\
\text { treatment) } \\
\text { RR group (Rehmanniae Radix } \\
\text { Preparata treatment) } \\
\text { CF group (Corni Fructus } \\
\text { treatment) } \\
\text { RC group (RC treatment) }\end{array}$ & $\begin{array}{l}\text { Acetamidovalerate, } \\
\text { glutamine, } \\
\text { phenyllactic acid, } \\
\text { tryptophan, } \\
\text { 7-ketolithocholic } \\
\text { acid and } \\
\text { deoxycholic acid. }\end{array}$ & $\begin{array}{l}\text { 1. Treatment with Rehmanniae Radix } \\
\text { and Corni Fructus showed an } \\
\text { increase in the relative abundance of } \\
\text { beneficial gut microbiota } \\
\text { (Ruminococcaceae UCG-014, } \\
\text { Ruminococcus 1, } \\
\text { Prevotellaceae_NK3B31_group, } \\
\text { Lachnospiraceae NK4A136 group, } \\
\text { and Lachnospiraceae UCG-001). } \\
\text { 2. Fecal metabolites } \\
\text { (Acetamidovalerate, glutamine, } \\
\text { phenyllactic acid, tryptophan, } \\
\text { 7-ketolithocholic acid, and } \\
\text { deoxycholic acid), involved in amino } \\
\text { acid metabolism, bile acids } \\
\text { metabolism and } \\
\text { glycerophospholipid metabolism, } \\
\text { were associated with CKD. }\end{array}$ & $\begin{array}{l}\text { 16S rRNA gene } \\
\text { sequencing and } \\
\text { UPLC-Q-TOF- } \\
\text { MS/MS }\end{array}$ & (67) \\
\hline $\begin{array}{l}43 \text { CKD undergo } \\
\text { peritoneal dialysis } \\
\text { ( } 26 \text { completed the } \\
\text { follow-up) }\end{array}$ & $\begin{array}{l}2 \text { groups for } 12 \text { weeks } \\
\text { Group 1: Unripe banana flour } \\
\text { (UBF-48\% resistant starch for } 4 \\
\text { weeks > washout for } 4 \text { weeks }> \\
\text { placebo (waxy corn starch) for } 4 \\
\text { weeks. } \\
\text { Group 2: Placebo for } 4 \text { weeks > } \\
\text { washout for } 4 \text { weeks > UBF for } \\
4 \text { weeks. }\end{array}$ & $\begin{array}{l}\text { IS, PCS, and indole } \\
\text { 3-acetic acid (IAA) }\end{array}$ & $\begin{array}{l}\text { 1. The serum levels of uremic toxins } \\
\text { (IS, PCS, and indole 3-acetic acid) } \\
\text { did not express any significant } \\
\text { change by UBF prebiotic treatment. } \\
\text { 2. IL-6 was slightly higher after } \\
\text { UBF treatment. }\end{array}$ & HPLC & (69) \\
\hline $\begin{array}{l}\text { Female C57BL/6J } \\
\text { (apoE KO mice) }\end{array}$ & $\begin{array}{l}14 \text { weeks before } \\
\text { tissue collection: } \\
\text { Group 1: Chow diet (control) } \\
\text { Group 2: Control + } 0.06 \% \\
\text { iodomethylcholine (IMC) } \\
\text { Group 3: Control }+0.2 \% \\
\text { adenine } \\
\text { Group 4: Control + } 0.2 \% \\
\text { adenine }+0.06 \% \mathrm{IMC}\end{array}$ & TMAO and TMA & $\begin{array}{l}\text { 1. Adenine diet is associated with CKD } \\
\text { progression, increasing plasma level } \\
\text { of TAMO, and inducing myocardial } \\
\text { hypertrophy. } \\
\text { 2. Supplementation of IMC in group } 2 \\
\text { and group } 3 \text { showed improvement } \\
\text { of renal injury and decreased plasma } \\
\text { TAMO than in group } 1 \text { and group } 3 \text {, } \\
\text { respectively. } \\
\text { 3. Controlling the TAMO level can be a } \\
\text { targeted treatment for CKD. }\end{array}$ & LC-MS & (70) \\
\hline
\end{tabular}


TABLE 3 | Continued

\begin{tabular}{|c|c|c|c|c|c|}
\hline CKD model & Dietary regimen & $\begin{array}{l}\text { Microbial related } \\
\text { metabolite (s) }\end{array}$ & Main findings & Technique(s) & Study \\
\hline $\begin{array}{l}\text { Female Virgin } \\
\text { Sprague-Dawley rats } \\
\text { (Maternal adenine } \\
\text { induced CKD) }\end{array}$ & $\begin{array}{l}3 \text { groups for } 18 \text { weeks } \\
\text { Group } 1 \text { (Control): Regular diet } \\
3 \text { weeks > regular diet for } 6 \\
\text { weeks (pregnancy and lactation) } \\
\text { > Regular diet (Male offspring till } \\
3 \text { months age). } \\
\text { Group } 2 \text { (CKD): Control diet + } \\
\text { adenine for } 3 \text { weeks > regular } \\
\text { diet for } 6 \text { weeks > Regular diet } \\
\text { (Male offspring till } 3 \text { months age). } \\
\text { Group } 3 \text { (CKD+R): Control diet } \\
+ \text { adenine for } 3 \text { weeks > } \\
\text { Regular diet + resveratrol for } 6 \\
\text { weeks > Regular diet (Male } \\
\text { offspring till } 3 \text { months age). }\end{array}$ & $\begin{array}{l}\text { Plasma TMA, } \\
\text { plasma TMAO and } \\
\text { fecal SCFAs }\end{array}$ & $\begin{array}{l}\text { 1. Resveratrol treatment showed a } \\
\text { protective effect against } \\
\text { hypertension in the adult male } \\
\text { offspring of maternal CKD. } \\
\text { 2. Resveratrol beneficially modifies the } \\
\text { gut microbiota by increasing the } \\
\text { abundance of the genera } \\
\text { Lactobacillus and Bifidobacterium } \\
\text { and decreasing the Firmicutes to } \\
\text { Bacteroidetes ratio. } \\
\text { 3. The plasma TMA significantly } \\
\text { increased in the resveratrol treated } \\
\text { group than the CKD group with } \\
\text { decreasing TMAO-to-TMA ratio. } \\
\text { 4. The male offspring's kidneys } \\
\text { expressed increasing G-protein } \\
\text { coupled receptor-41 (GPR41) } \\
\text { protein levels in the resveratrol } \\
\text { treated group. }\end{array}$ & $\begin{array}{l}\text { 16s rRNA gene } \\
\text { sequencing and } \\
\text { LC-MS }\end{array}$ & (71) \\
\hline $\begin{array}{l}\text { C57BL6 } \\
\text { Mic 5/6 nephrectomy } \\
\text { CKD-induced and } \\
\text { healthy controls }\end{array}$ & $\begin{array}{l}\text { Four groups (4 weeks) } \\
\text { Group 1: Control mice + regular } \\
\text { diet. } \\
\text { Group 2: Control mice + high } \\
\text { fiber diet (Resistant starch). } \\
\text { Group 3: CKD-induced mice+ } \\
\text { regular diet. } \\
\text { Group 4: CKD-induced mice + } \\
\text { high fiber diet. }\end{array}$ & NA & $\begin{array}{l}\text { 1. Healthy mice fed with a resistance } \\
\text { starch (HRS) diet showed } \\
\text { upregulation in tryptophan and } \\
\text { indole metabolism compared with } \\
\text { CKD and CDK-RS groups. } \\
\text { 2. RS diet reduced CKD progression } \\
\text { compared with regular diet in CKD } \\
\text { mice. } \\
\text { 3. RS increased the abundance of } \\
\text { beneficial bacteria } \\
\text { (butyrate-producing bacteria) and } \\
\text { decreased mucin-degrading } \\
\text { bacteria. } \\
\text { 4. Oscillibacter sp. 1-3 was the most } \\
\text { abundant bacterium in healthy mice } \\
\text { fed with RS }\end{array}$ & $\begin{array}{l}\text { de novo } \\
\text { sequencing using } \\
\text { PEAKS }\end{array}$ & (72) \\
\hline $\begin{array}{l}28 \text { CKD dogs and } 28 \\
\text { healthy dogs }\end{array}$ & $\begin{array}{l}\text { Six groups ( } 30 \\
\text { weeks interventions } \\
\text { Group 1: Control food ( } 10 \\
\text { weeks) > Low soluble fiber plus } \\
\text { betaine food ( } 10 \text { weeks) > High } \\
\text { soluble fiber plus betaine food } \\
\text { (10 weeks). } \\
\text { Group 2: Control food ( } 10 \\
\text { weeks) > High soluble fiber plus } \\
\text { betaine food ( } 10 \text { weeks) > Low } \\
\text { soluble fiber plus betaine food } \\
\text { (10 weeks). }\end{array}$ & $\begin{array}{l}\text { SCFAs and uremic } \\
\text { toxins }\end{array}$ & $\begin{array}{l}\text { 1. CKD dogs expressed a lower level } \\
\text { of SCFAs and higher levels of } \\
\text { gut-related uremic toxins, creatinine, } \\
\text { urea, and indoles than healthy } \\
\text { controls. } \\
\text { 2. The low soluble fiber plus betaine } \\
\text { food significantly reduced genus } \\
\text { Collinsella of (phylum Actinobacteria) } \\
\text { compared with the control food and } \\
\text { the high soluble fiber plus betaine } \\
\text { food. }\end{array}$ & $\begin{array}{l}16 \mathrm{~S} \text { rRNA gene } \\
\text { sequencing \& } \\
\text { LC-MS }\end{array}$ & (74) \\
\hline
\end{tabular}


TABLE 3 | Continued

\begin{tabular}{|c|c|c|c|}
\hline CKD model & Dietary regimen & $\begin{array}{l}\text { Microbial related } \\
\text { metabolite (s) }\end{array}$ & Main findings \\
\hline & $\begin{array}{l}\text { Group 3: Low soluble fiber plus } \\
\text { betaine food (10 weeks) > } \\
\text { Control food ( } 10 \text { weeks) > High } \\
\text { soluble fiber plus betaine food } \\
\text { (10 weeks). } \\
\text { Group 4: Low soluble fiber plus } \\
\text { betaine food (10 weeks) > High } \\
\text { soluble fiber plus betaine food } \\
\text { (10 weeks) > Control food ( } 10 \\
\text { weeks). } \\
\text { Group 5: High soluble fiber plus } \\
\text { betaine food (10 weeks) > }\end{array}$ & & $\begin{array}{l}\text { 3. The highest abundance of Phylum } \\
\text { Bacteroidetes (genus Odoribacter) } \\
\text { was in the low soluble fiber plus } \\
\text { betaine food, followed by the control } \\
\text { food, and the high soluble fiber plus } \\
\text { betaine food had the lowest } \\
\text { abundance. } \\
\text { CKD dogs consuming low soluble fiber } \\
\text { plus betaine and the high soluble fiber } \\
\text { plus betaine foods expressed a } \\
\text { healthier profile than CKD dogs fed with } \\
\text { control food. }\end{array}$ \\
\hline
\end{tabular}

Wistar rats $(5 / 6$ nephrectomy and sham controls)

CKD cats and healthy controls cats

Virgin

Sprague-Dawley rats (Maternal CKD model)
Control food (10 weeks) > Low soluble fiber plus betaine food (10 weeks).

Group 6: High soluble fiber plus betaine food (10 weeks) > > Low soluble fiber plus betaine food (10 weeks) > Control food (10 weeks).

Two groups (8 weeks)

Normal diet group For nephrectomy rats $(\mathrm{Nx})$ and sham control rats

Normal diet + paramylon group For nephrectomy rats (Nx+PAR)

Pre-trial food: Diet ${ }^{\circledR} \mathrm{k} / \mathrm{d}^{\circledR}$ Feline with chicken, dry for 14 days Group 1(Food A for 4 weeks): Pre-trial food + betaine $(0.500 \%)$ + oat beta glucan $(0.586 \%)+$ $0.407 \%$ scFOS.

Group 2 (Food B for 4 weeks): Pre-trial food + betaine $(0.500 \%)$ + oat beta glucan $(0.586 \%)+$ $3.44 \%$ apple pomace

Pregnancy intervention
(3 weeks)
Group 1: Control Mice + Vehicle
Group 2: Control Mice +
Tryptophan
Group 3: CKD + Vehicle
Group 4: CKD + Tryptophan

Tricarboxylic acid cycle-related metabolites (cis-aconitic acid, citric acid, isocitric acid, and malic acid)

Creatinine, urea, and some microbial and host tryptophan metabolites (indole sulfates and kynurenate).

Nitric oxid-related metabolites, including I-citrulline (the precursor of I-arginine), I-arginine
1. Nxand Nx + PAR groups exhibited a lower abundance of Lactobacillus and Rothia and a higher abundance of Clostridium than the sham control group.

2. Paramylon supplementation (Nx+ PAR) significantly increased the abundance of Eubacterium, Marvinbryantia, Parvibacter, Coprococcus, Robinsoniella, and Bacillus compared with NX with a regular diet.

3. Paramylon improved renal function (reduce tubulointerstitial injury and glomerulosclerosis) and inhibited the accumulation of uremic toxins like tricarboxylic acid cycle-related metabolites and gut-derived metabolites.

1. The plasma levels of creatinine, urea, indole sulfates, and kynurenate were higher in CKD cats than controls at the baseline of the interventions.

2. CKD cats-Food B group showed higher levels of more oxidized glutathione and inflammatory sphingolipid metabolites than CKD cats-Group A.

3. The relative abundance of Bacteroidales was higher in CKD cats-Food A than in CKD cats at the baseline.

1. The relative abundance of the genera Lactobacillus and Ruminiclostridium_9, decreased in maternal CKD, while genus Ruminococcus_1 increased.

2. Male offspring of maternal CKD rats expressed hypertension, but tryptophan supplementation during pregnancy prevented it.
16S rRNA gene sequencing \& CE-TOFMS
16S rRNA gene Sequencing \& LC-MS \& GC-MS

16S rRNA gene sequencing and HPLC
Study

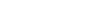


TABLE 3 | Continued

\begin{tabular}{ll}
\hline CKD model & Dietary regimen \\
& \\
\hline & Male offspring intervention \\
& (12 weeks) \\
& Group 1: Vehicle (CN) \\
Group 2: CKD \\
Group 3: Tryptophan \\
supplementation (Trp) \\
Group 4: CKD + Tryptophan \\
supplementation (CKDTrp)
\end{tabular}

$\begin{array}{ll}\text { Male C57BL/6JJcl } & 4 \text { groups (4 weeks intervention) } \\ \text { mice } & \text { Group 1: Control Mice + Vehicle } \\ & \text { Group 2: Control Mice + } \\ & \text { AST-120 (carbon absorbent) } \\ & \text { Group 3: Renal failure (RF) + } \\ & \text { Vehicle } \\ & \text { Group 4: Renal failure } \\ & + \text { AST-120 }\end{array}$

Male C57BL/6J mice Four groups (5 weeks intervention)

Group 1 (control): Standard normal rodent diet without choline

Group 2: Control diet + TMAO Group 3: Control diet + choline Group 4: Control diet + choline + iodomethylcholine (IMC) All groups treated with isoproterenol interventions for 28 days.

60 CKD patients (grades 3B-4), randomly assigned for two groups.

Group 1: Free diet (3 months) > very low protein diet (6 months) $>$ free diet (3 months) >

Mediterranean diet (6 months). after one week of the

\section{Microbial related} metabolite (s)

Main findings

Technique(s)

Study

Group 2: Free diet (3 months) > Mediterranean diet (6 months) > free diet (3 months) > very low protein diet (6 months).

\section{IS \& PCS}

TMAO and its precursor choline

3. Increasing phylum Firmicutes and reduction of Bacteroidetes were associated with maternal tryptophan supplementation.

4. Trp and CKDTrp interventions increased the Firmicutes to Bacteroidetes ratio compared with the control group.

5. Tryptophan is thought to prevent hypertension by controlling nitric oxide and the renin-angiotensin system pathways and modulating tryptophan-metabolizing microbes.

1. The RF group had decreased Bacteroidetes and increased Firmicutes compared to the control.

2. AST-120 treatment affected the PCS and IS levels, the relative abundance on gut microbiota, and metabolic enzymes associated with p-cresol and tryptophan production.

3. RF mice treated with AST-120 expressed an increase in the relative abundance of Faecalibaculum, Blautia and Desulfovibrio, and a decrease in the relative abundance of Roseburia.

1. TMAO and choline diets were associated with renal functions impairment and renal fibrosis, while IMC supplementation showed significant improvement in renal functional metrics.

2. The relative abundance of Bacteroides was lower in the TAMO and choline groups than in the control group, and the addition of IMC reversed this effect.

3. Group 2 and group 3 diets had a marked enrichment of Lachnospiraceae_UCG-002 with a positive correlation of Cystatin $\mathrm{C}$ and ACR and a negative correlation with GFR.

IS PCS

1. The uremic toxins (IP and PCS) levels were negatively correlated with very low protein and Mediterranean diets.

2. Very low protein and Mediterranean diets significantly increased butyrate-forming bacteria (Lachnospiraceae,

Ruminococcaceae, Prevotellaceae, and Bifidobacteriaceae) and reduced Enterobacteriaceae (harmful).

3. The very low protein diet showed enrichment of Blautia and Faecalibacterium, Coprococcus, and Roseburia species (beneficial modulation of gut microbiota).
16 S rRNA gene Sequencing and GC-MS

16S rRNA gene sequencing and LC-MS/MS

16s rRNA gene LC-MS/MS sequencing and
(78)

(79) 
TABLE 3 | Continued

\begin{tabular}{|c|c|c|c|c|c|}
\hline CKD model & Dietary regimen & $\begin{array}{l}\text { Microbial related } \\
\text { metabolite (s) }\end{array}$ & Main findings & Technique(s) & Study \\
\hline $\begin{array}{l}21 \text { CKD patients on } \\
\text { hemodialysis patients } \\
\text { (10 Placebo group and } \\
11 \text { Probiotic group) }\end{array}$ & $\begin{array}{l}\text { Placebo group: Three capsules } \\
\text { (wheat germ) per day for } 3 \\
\text { months } \\
\text { Probiotics group: Three } \\
\text { capsules (Streptococcus } \\
\text { thermophilus (KB19), Lactobacillus } \\
\text { acidophilus (KB27), } \\
\text { and Bifidobacteria } \\
\text { longum (KB31)) Per day for } \\
3 \text { months. }\end{array}$ & $\begin{array}{l}\text { TMAO and } \\
\text { TAMOA precursors } \\
\text { (choline, betaine) }\end{array}$ & $\begin{array}{l}\text { 1. Probiotic supplementation didn't } \\
\text { affect the TMAO level but } \\
\text { significantly increased the betaine } \\
\text { level. } \\
\text { 2. In the placebo group, the choline } \\
\text { level was increased. }\end{array}$ & LC-MS/MS & (34) \\
\hline Sprague-Dawley rats & $\begin{array}{l}\text { Salviae Miltiorrhizae Radix et } \\
\text { Rhizoma (SMR) treatment (4 } \\
\text { weeks). } \\
\text { Group A: Normal rat model } \\
\text { Group B: Chronic renal failure } \\
\text { rat model }\end{array}$ & $\begin{array}{l}\text { Dihydrotanshinone I } \\
\text { and miltirone }\end{array}$ & $\begin{array}{l}\text { 1. Gut microbiota Mucispirillum, } \\
\text { Kurthia, Clostridium, Blautia, } \\
\text { Butyrivibrio, Shuttleworthia, } \\
\text { Peptococcus, Ruminococcus, } \\
\text { Bradyrhizobium, Methylobacterium, } \\
\text { Azospirillum, Thalassospira, } \\
\text { Methylophilus, Pseudomonas, } \\
\text { peptostreptococcaceae and } \\
\text { bacteroidales showed a significant } \\
\text { change after SMR treatment. } \\
\text { 2. The modulatory effect of SMR on } \\
\text { the gut microbiota is thought to be } \\
\text { promoted by the bioactive materials } \\
\text { (tanshinones and salvianolic acids). }\end{array}$ & $\begin{array}{l}\text { 16s rRNA gene } \\
\text { sequencing } \\
\text { UPLC-QTOF/MS }\end{array}$ & (80) \\
\hline $\begin{array}{l}\text { Sprague-Dawley rat } \\
\text { (5/6 nephrectomy } \\
\text { CKD and sham } \\
\text { controls) }\end{array}$ & $\begin{array}{l}\text { Four groups for } 8 \\
\text { weeks interventions } \\
\text { Group 1: Sham rats + vehicle } \\
\text { (tap water) } \\
\text { Group 2: Sham rats }+3,3 \\
\text { dimethyl-1-butanol (DMB) } \\
\text { Group 3: CKD rats + vehicle } \\
\text { Group 4: CKD rats + DMB }\end{array}$ & TAMO & $\begin{array}{l}\text { 1. The serum level of TAMO was } \\
\text { significantly high in the CKD-Vehicle } \\
\text { group compared with the } \\
\text { sham-vehicle group. } \\
\text { 2. TAMO is associated with elevation of } \\
\text { proinflammatory cytokines and } \\
\text { oxidative stress. } \\
\text { 3. DMB (TMAO inhibitor) partially } \\
\text { neutralize the effect of TAMO. }\end{array}$ & LC-MS & (81) \\
\hline $\begin{array}{l}\text { Male Sprague-Dawley } \\
\text { rats (CKD and } \\
\text { cecectomized rats }\end{array}$ & $\begin{array}{l}\text { Two groups ( } 24 \\
\text { weeks intervention) } \\
\text { Group 1: CKD rats } \\
\text { Group 2: CKD rats + AST-120 } \\
\text { treatment (carbon absorbent) }\end{array}$ & IS and phenyl sulfate & $\begin{array}{l}\text { 1. Uremic toxins (IS and phenyl sulfate) } \\
\text { in urine and serum were higher in } \\
\text { the CKD rats compared with the } \\
\text { control rats. } \\
\text { 2. CKD and CKD + AST-120 rats } \\
\text { showed lower diversity and richness } \\
\text { than control rats. } \\
\text { 3. Treatment with AST-120 decreased } \\
\text { the uremic toxins levels. } \\
\text { 4. Cecectomized rats expressed a } \\
\text { change in the uremic toxins } \\
\text { production and gut microbiota } \\
\text { composition (production depends } \\
\text { on endogenous gut microbiota). } \\
\text { 5. Indole and phenol-producing gut } \\
\text { bacteria (belongs to Clostridia and } \\
\text { Bacteroidia) significantly reduced the } \\
\text { relative abundance in } \\
\text { cecectomized rats. }\end{array}$ & $\begin{array}{l}\text { LC-MS and } 454- \\
\text { pyrosequencing of } \\
\text { the } 16 \mathrm{~S} \text { rRNA } \\
\text { gene }\end{array}$ & (82) \\
\hline
\end{tabular}


TABLE 3 | Continued

\begin{tabular}{|c|c|c|c|c|c|}
\hline CKD model & Dietary regimen & $\begin{array}{l}\text { Microbial related } \\
\text { metabolite (s) }\end{array}$ & Main findings & Technique(s) & Study \\
\hline $\begin{array}{l}\text { Male Sprague-Dawley } \\
\text { rats } \\
\text { Sham controls and } \\
\text { Uremia (CKD-induced) }\end{array}$ & $\begin{array}{l}\text { Three groups (4 weeks) } \\
\text { Group 1: Sham controls } \\
\text { Group 2: Uremia } \\
\text { Group 3: Uremia + Probiotic } \\
\text { (Lactobacillus } L B \text { ) All groups } \\
\text { were fed with standard diet. }\end{array}$ & Fecal metabolites & $\begin{array}{l}\text { 1. CKD-induced rats showed alteration } \\
\text { in the fecal compared with controls; } \\
\text { Lactobacillus intervention partially } \\
\text { overturned these changes. } \\
\text { 2. The fecal docosahexaenoic acid, } \\
\text { 3-(3-hydroxyphenyl) propionic acid, } \\
\text { phenethylamine glucuronide, } \\
\text { stearoyl serotonin, and } \\
\text { aspartyl-glutamine metabolites were } \\
\text { significantly decreased after } \\
\text { probiotic treatment. }\end{array}$ & UPLC-MS & (83) \\
\hline $\begin{array}{l}\text { Male Sprague-Dawley } \\
\text { rats (adenine-induced } \\
\text { CKD) }\end{array}$ & $\begin{array}{l}\text { Group 1: Semipurified low-fiber } \\
\text { diet for } 3 \text { weeks. } \\
\text { Group 2: High-fiber diet } \\
\text { Resistant starch (HAMRS2) for } \\
3 \text { weeks. }\end{array}$ & IS, PCS & $\begin{array}{l}\text { 1. The high fiber diet increased } \\
\text { decreased the serum and urine } \\
\text { levels of IS and PCS metabolites. } \\
\text { 2. Rats fed with a high fiber diet } \\
\text { showed an increase in the } \\
\text { Bacteroidetes-to-Firmicutes ratio } \\
\text { than those fed with a low fiber diet. } \\
\text { 3. The high fiber diet was positively } \\
\text { correlated with the relative } \\
\text { abundance of Actinobacteria and Protec }\end{array}$ & $\begin{array}{l}\text { 16s rRNA gene } \\
\text { sequencing and } \\
\text { GC-TOF/MS } \\
\text { bacteria. }\end{array}$ & (35) \\
\hline 40 CKD patients & $\begin{array}{l}\text { Two groups for } 12 \text { weeks } \\
\text { Group 1: prebiotic arabinoxylan } \\
\text { oligosaccharides (AXOS) ( } 10 \mathrm{~g} \\
\text { twice daily) and maltodextrin for } \\
4 \text { weeks }>\text { washout ( } 4 \text { weeks) > } \\
\text { Placebo (potato starch) } 4 \text { weeks. } \\
\text { Group 2: Placebo for } 4 \text { weeks > } \\
\text { washout (4 weeks) > AXOS and } \\
\text { maltodextrin for } 4 \text { weeks }\end{array}$ & $\begin{array}{l}\text { PCS, IS, TMAO, } \\
\text { p-cresyl } \\
\text { glucuronide, and } \\
\text { phenylacetylglutamine. }\end{array}$ & $\begin{array}{l}\text { 1. Gut related uremic toxins and insulin } \\
\text { resistance did not show any } \\
\text { significant change after } \\
\text { prebiotic treatment. }\end{array}$ & UPLC-MS/MS & (84) \\
\hline
\end{tabular}

${ }^{*}$ The study also included in Table 1, IS, Indoxyl sulfate; PCS, p-cresyl sulfate; TMAO, trimethylamine N-oxide; TMA, trimethylamine; SCFAs, short chain fatty acids; NA, not applicable; GFR, glomerular filtration rate; LC, liquid chromatography; GC, gas chromatography; MS, mass spectrometer; HPLC, high performance liquid chromatography; UPLC, ultraperformance liquid chromatography; TOF-MS, time-of-flight mass spectrometry-based approach.

Another mechanism by which gut dysbiosis may contribute to $\mathrm{CKD}$ progression is via the role of gut dysbiosis in endothelial dysfunction, the vasoconstrictor response, and the subsequent development of hypertension; a well-known risk factor for $\operatorname{CKD}(94,95)$. Mice fed a high-salt diet had aberrant microbiota compared with mice fed a normal diet; these changes were associated with activation of Tlymphocytes and an elevation in blood pressure (96). A lower abundance of Lactobacillus species in the gut is associated with the development of hypertension and kidney diseases (97). Changes in the gut microbiota could be the starting point for CKD progression through a series of immune response modifications, blood pressure alterations, metabolic changes, and prolonged inflammation.

\section{MICROBIAL METABOLITES IN CKD}

In general, microbial metabolites associated with CKD are classified into two groups; harmful and renoprotective metabolites. This bi-direction relationship of microbialderived metabolites is illustrated in Figure 2. Several human and animal studies have demonstrated the deleterious effects of TAMO on the kidney, manifested as kidney interstitial fibrosis, eGFR decline, endothelial dysfunction, and an increased risk of cardiovascular disease risk $(34,36,47,81)$. The increased risk of mortality and morbidity in patients with CKD has been attributed to the accumulation of indoxyl sulfate and $p$-cresyl sulfate $(27,28,33,39)$. These toxins bind with high affinity to plasma proteins, which mitigates their 


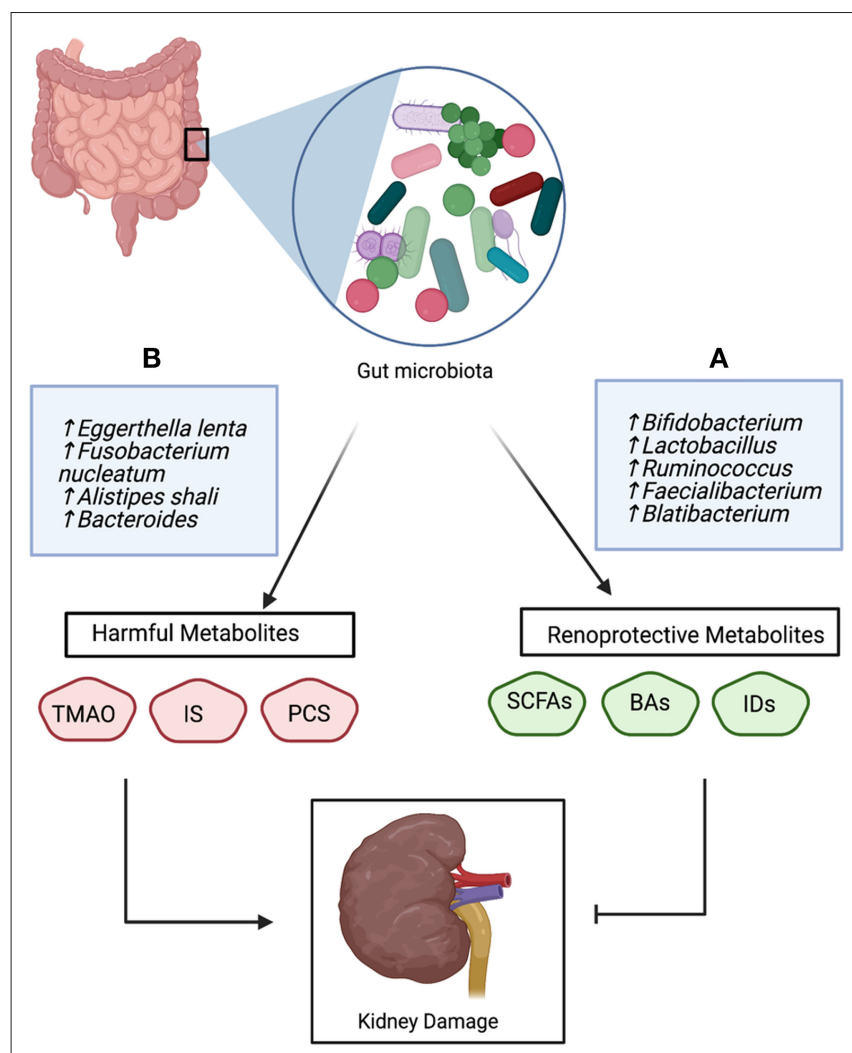

FIGURE 2 | The bidirectional role of gut-derived metabolites in the pathophysiology of CKD; (A) Beneficial bacteria produce renoprotective metabolites that inhibit kidney damage, (B) Unfavorable bacteria produce harmful metabolites which promote kidney damage and CKD progression. Trimethylamine $\mathrm{N}$-oxide (TMAO), indoxyl sulfate (IS), p-cresyl sulfate (PSC), short-chain fatty acids (SCFAs), bile acids (Bas), and Indole derivatives (IDs).

removal through the dialysis membrane (28). TAMO, indoxyl sulfate, and $p$-cresyl sulfate are involved in SMAD signaling, tryptophan metabolism, and tyrosine pathways, respectively $(20,46,54)$.

A wide array of uremic toxins and other microbial metabolites accumulate in biological samples of patients with $\mathrm{CKD}$, including those in common biological samples such as plasma, stool, and urine, but also volatile metabolites in exhaled breath and gases collected from fecal cultures. For example, accumulation of gaseous metabolites including isoprene, aldehyde, dimethyldisulfide, dimethyltrisulfide, and thioesters occurs in patients with CKD (65).

\section{DIETARY INTERVENTIONS AND CKD}

Microbial dysbiosis and accumulation of gut-derived metabolites have been reported in CKD patients $(20,29,53)$. Randomized controlled clinical trials in patients with CKD indicate that changes in the composition of the gut microbiota after treatment with prebiotics and probiotics improved disease outcomes and reduced uremic toxin levels (98-100). Patients with a high abundance of Bifidobacterium and Lactobacillus had lower serum levels of uremic toxins, a reduced inflammatory milieu, and improved renal function $(98,101)$.

The consumption of food items rich in choline and Lclaritin-which are precursors of TAMO-such as egg yolk, kidney, liver, meat and milk, correlates with a high accumulation of uremic toxin and a decline in the glomerular filtration rate (102). A prospective, crossover clinical trial randomized 60 patients with CKD to different dietary interventions; the group on the very low-protein diet had an increase in the gut abundance of Actinobacteria and a decrease in the inflammatory Proteobacteria compared with the group on a regular diet (27).

Prebiotics are non-digestible dietary components such as dietary fiber and digestion-resistant starch. They are present in cereals, fruits, milk, honey, and vegetables or can be given as a dietary supplement (103). Fermentation of prebiotics beneficially modifies gut bacteria by increasing the abundance of Bifidobacterium spp and lactobacillus and reducing the levels of Bacteroides, Clostridia, and Enterobacteria (104). In patients with CKD, dietary fiber intake decreases the levels of circulating pro-inflammatory cytokines, slows the decline in eGFR, lowers the plasma levels of uremic toxins, and minimizes CKDrelated cardiovascular risk $(105,106)$. Esgalhado and colleagues studied the effect of digestion-resistant starch supplementation (16 g/day) in patients with $\mathrm{CKD}$; they observed a reduction in the plasma levels of uremic toxins (indoxyl sulfate, and $p$ cresyl sulfate), interleukin (IL)-6, and thiobarbituric acid-reactive substances (107). These results are consistent with another study of 32 patients with CKD randomized into two groups; the group that received lactulose syrup for 8 weeks had a greater abundance Bifidobacterium and Lactobacillus in the gut microbiome and decreased serum creatinine levels (108). While these studies demonstrated that probiotics and prebiotics have a beneficial effect on CKD, other studies have shown no significant changes in circulating gut-derived metabolites or changes in CKD outcomes $(34,84)$. It is important to point out that existing studies are heterogeneous; they used different dietary supplements, had varying durations of intervention, and administered to patients with other comorbidities, patients with varying kidney disease severity and varying underlying etiology. This heterogeneity makes it extremely difficult to draw conclusions from these studies. That being said, superior results may be obtained from the study of dietary interventions in children as other cofounding factors are minimal.

Overall, these studies imply that nutrition therapy has the potential to modulate the microbiome composition and its metabolites, and consequently ameliorate CKD complications and the rate of CKD progression. However, further well-designed, prospective studies are needed to definitively demonstrate the benefit of nutrition therapy on CKD.

\section{ROLE OF THE URINARY AND BLOOD MICROBIOMES IN CKD}

Most of the attention in the microbiome field is on the gut microbiota and its metabolites; however, the urinary microbiome 
is receiving more attention. Until recently, urine was considered a sterile fluid that was only rendered unsterile because of infection $(109,110)$. But the development of next-generation sequencing techniques enabled studies showing that the urinary tract of healthy individuals is dominated by different kinds of microbes, and the distribution pattern of these microbes affects the health of urinary tract health $(110,111)$. Fluctuation in the urinary microbiome occurs in urinary tract infections and is involved in antibiotic resistance $(109,112)$. The urinary microbiome undergoes changes after kidney transplantation, and these modifications thought to be responsible for allograft dysfunction and increased susceptibility to infection $(113,114)$. In addition, the diversity in microbes in the urinary tract of patients with CKD is associated with the eGFR value (115).

The circulatory microbiome in healthy individuals contains diverse bacterial taxa, and the dominated phylum is Proteobacteria (38). Gut-derived endotoxins circulating in the bloodstream were shown to alter the blood microbiome (93). A study investigating the correlation between blood metabolome and $\alpha$-diversity of gut microbiota on 399 participants indicated that gut-derived metabolites like p-cresyl and TAMO reflect the Shannon diversity of gut bacteria and could be a biomarker reflecting the gut health (116). A case-controlled study using $16 \mathrm{~S}$ rRNA target sequencing of blood samples showed that compared with control groups, patients with CKD had a higher diversity of Enterobacteriaceae and Pseudomonadaceae, which was also correlated with lower eGFR (117). Hence, we see the gut microbiota has an ultimate effect on CKD outcomes through different routes.

\section{CONCLUSION}

Microbial dysbiosis plays an important role in the pathogenesis of various diseases. In this review, we summarized and reviewed the literature examining the dual role of the gut

\section{REFERENCES}

1. Lv J, Zhang L. Prevalence and disease burden of chronic kidney disease. $A d v$ Exp Med Biol. (2019) 1165:3-15. doi: 10.1007/978-981-13-8871-2_1

2. Gorostidi M, Sánchez-Martínez M, Ruilope LM, Graciani A, de la Cruz JJ, Santamaría R, et al. Chronic kidney disease in Spain: prevalence and impact of accumulation of cardiovascular risk factors. Nefrologia. (2018) 38:606-15. doi: 10.1016/j.nefroe.2018.04.010

3. Black LM, Lever JM, Traylor AM, Chen B, Yang Z, Esman SK, et al. Divergent effects of AKI to CKD models on inflammation and fibrosis. Am J Physiol Renal Physiol. (2018) 315:F1107-18. doi: 10.1152/ajprenal.00179.2018

4. Kumar S. Cellular and molecular pathways of renal repair after acute kidney injury. Kidney Int. (2018) 93:27-40. doi: 10.1016/j.kint.2017.07.030

5. Negi S, Koreeda D, Kobayashi S, Yano T, Tatsuta K, Mima T, et al. Acute kidney injury: epidemiology, outcomes, complications, and therapeutic strategies. Semin Dial. (2018) 31:519-27. doi: 10.1111/sdi.12705

6. Tiewsoh K, Soni A, Dawman L, Peters NJ, Malik MA. Chronic peritoneal dialysis in children with chronic kidney disease: An experience from a North Indian teaching institute. J Fam Med Prim Car. (2021) 10:3682-7. doi: 10.4103/jfmpc.jfmpc_250_21

7. Kaur G, Singh J, Kumar J. Vitamin D and cardiovascular disease in chronic kidney disease. Pediatr Nephrol. (2019) 34:2509-22. doi: 10.1007/s00467-018-4088-y microbiome and its metabolic products in the pathophysiology and progression of CKD. We described how gut dysbiosis can initiate the inflammatory process and cause leaking of gutderived metabolites into the bloodstream. It is well-established that TAMO, indoxyl sulfate, and p-cresyl sulfate and other harmful microbial metabolites accumulate in patients with CKD, and levels of these metabolites correlate with disease progression. Lower levels of bifidobacterium, lactobacillus, and bile acid composition are linked to adverse outcomes in patients with CKD. Our analysis of the literature suggests that the complex interaction between the gut, urinary tract and blood microbiota and associated metabolites may orchestrate subclinical changes in the pathogenesis of CKD and contribute to disease. Modulating the gut microbiota using dietary interventions could improve the clinical outcomes of patients with CKD. Our recommendations are i. conducting omics-based studies like metagenomics and metatranscriptomics to identify the gut microbiota community, metabolic pathways, and microbial genes associated with CKD. ii. screening gut microbiota at different disease stages, especially at the early disease stages. iii. performing dietary intervention studies for CKD patients in the early stages. iv. assessment of urinary and blood microbiome studies for CKD patients. These directions may give a clue about the disease etiology, metabolic pathways and potential treatment for CKD.

\section{AUTHOR CONTRIBUTIONS}

EW wrote the first draft. IS and SA reviewed and finalized the content of the manuscript. All authors read and approved the final version.

\section{FUNDING}

This work is funded by Sidra Medicine Internal Research Fund 2019 (No. SDR 200055).

8. Chang C, Fan P, Kuo G, Lin Y, Tsai T, Chang S, et al. Infection in advanced chronic kidney disease and subsequent adverse outcomes after dialysis initiation: a nationwide cohort study. Sci Rep. (2020) 10:2938. doi: 10.1038/s41598-020-59794-7

9. Sárközy M, Kovács ZZA, Kovács MG, Gáspár R, Szucs G, Dux L. Mechanisms and modulation of oxidative/nitrative stress in type 4 cardio-renal syndrome and renal sarcopenia. Front Physiol. (2018) 9:1648. doi: 10.3389/fphys.2018.01648

10. Mazumder MK, Paul R, Bhattacharya P, Borah A. Neurological sequel of chronic kidney disease: from diminished acetylcholinesterase activity to mitochondrial dysfunctions, oxidative stress and inflammation in mice brain. Sci Rep. (2019) 9:3097. doi: 10.1038/s41598-018-37935-3

11. Piccoli GB, Cabiddu G, Attini R, Vigotti FN, Maxia S, Lepori N, et al. Risk of adverse pregnancy outcomes in women with CKD. J Am Soc Nephrol. (2015) 26:2011-22. doi: 10.1681/ASN.2014050459

12. Kovesdy CP. Management of hyperkalaemia in chronic kidney disease. Nat Rev Nephrol. (2014) 10:653-62. doi: 10.1038/nrneph.2014.168

13. Chou H, Lin C, Chiou Y, Tain Y, Wang Y, Wang H, et al. Clinical characteristics and prevalence of complications of chronic kidney disease in children: the Taiwan pediatric renal collaborative study. Pediatr Nephrol. (2016) 31:1113-20. doi: 10.1007/s00467-016-3325-5

14. Ishikura K, Uemura O, Hamasaki $\mathrm{Y}$, Ito $\mathrm{S}$, Wada $\mathrm{N}$, Hattori $\mathrm{M}$, et al. Progression to end-stage kidney disease in Japanese children with chronic 
kidney disease: results of a nationwide prospective cohort study. Nephrol Dial Transplant. (2014) 29:878-84. doi: 10.1093/ndt/gfu012

15. Furth SL, Pierce C, Hui WF, White CA, Wong CS, Schaefer F, et al. Estimating time to ESRD in children with CKD. Am J Kidney Dis. (2018) 71:783-92. doi: 10.1053/j.ajkd.2017.12.011

16. Gilbert J, Blaser MJ, Caporaso JG, Jansson J, Lynch SV, Knight R. Current understanding of the human microbiome. Nat Med. (2018) 24:392400. doi: $10.1038 / \mathrm{nm} .4517$

17. Sommer F, Anderson JM, Bharti R, Raes J, Rosenstiel P. The resilience of the intestinal microbiota influences health and disease. Nat Rev Microbiol. (2017) 15:630-8. doi: 10.1038/nrmicro.2017.58

18. Al Khodor S, Shatat IF. Gut microbiome and kidney disease: a bidirectional relationship. Pediatr Nephrol. (2017) 32:92131. doi: 10.1007/s00467-016-3392-7

19. Young VB. The role of the microbiome in human health and disease: an introduction for clinicians. BMJ. (2017) 356:j831. doi: 10.1136/bmj.j831

20. Wu I-W, Lin C-Y, Chang L-C, Lee C-C, Chiu C-Y, Hsu H-J, et al. Gut microbiota as diagnostic tools for mirroring disease progression and circulating nephrotoxin levels in chronic kidney disease: discovery and validation study. Int J Biol Sci. (2020) 16:420-34. doi: 10.7150/ijbs.37421

21. Pflughoeft KJ, Versalovic J. Human microbiome in health and disease. Annu Rev Pathol. (2012) 7:99-122. doi: 10.1146/annurev-pathol-011811-132421

22. Lloyd-Price J, Abu-Ali G, Huttenhower C. The healthy human microbiome. Genome Med. (2016) 8:51. doi: 10.1186/s13073-016-0307-y

23. Schugar R, Brown J. Emerging roles of flavin monooxygenase 3 in cholesterol metabolism and atherosclerosis. Curr Opin Lipidol. (2015) 26:426-31. doi: 10.1097/MOL.0000000000000215

24. Hsu C, Chang-Chien G, Lin S, Hou C, Lu P, Tain Y. Association of trimethylamine, trimethylamine $\mathrm{n}$-oxide, and dimethylamine with cardiovascular risk in children with chronic kidney disease. J Clin Med. (2020) 9:336. doi: $10.3390 / \mathrm{jcm} 9020336$

25. Kanemitsu Y, Mishima E, Maekawa M, Matsumoto Y, Saigusa D, Yamaguchi $\mathrm{H}$, et al. Comprehensive and semi-quantitative analysis of carboxylcontaining metabolites related to gut microbiota on chronic kidney disease using 2-picolylamine isotopic labeling LC-MS/MS. Sci Rep. (2019) 9:19075. doi: 10.1038/s41598-019-55600-1

26. Mishima E, Fukuda S, Mukawa C, Yuri A, Kanemitsu Y, Matsumoto Y, et al. Evaluation of the impact of gut microbiota on uremic solute accumulation by a CE-TOFMS-based metabolomics approach. Kidney Int. (2017) 92:63445. doi: 10.1016/j.kint.2017.02.011

27. Di Iorio BR, Rocchetti MT, De Angelis M, Cosola C, Marzocco S, Di Micco L, et al. Nutritional therapy modulates intestinal microbiota and reduces serum levels of total and free indoxyl sulfate and p-cresyl sulfate in chronic kidney disease (medika study). J Clin Med. (2019) 8:1424. doi: 10.3390/jcm8091424

28. Gryp T, De Paepe K, Vanholder R, Kerckhof F, Van Biesen W, Van de Wiele T, et al. Gut microbiota generation of protein-bound uremic toxins and related metabolites is not altered at different stages of chronic kidney disease. Kidney Int. (2020) 97:1230-42. doi: 10.1016/j.kint.2020.01.028

29. Pelletier CC, Croyal M, Ene L, Aguesse A, Billon-Crossouard S, Krempf $\mathrm{M}$, et al. Elevation of trimethylamine-N-oxide in chronic kidney disease: contribution of decreased glomerular filtration rate. Toxins. (2019) 11:635. doi: 10.3390/toxins11110635

30. Querfeld U, Anarat A, Bayazit AK, Bakkaloglu AS, Bilginer Y, Caliskan S, et al. The cardiovascular comorbidity in children with chronic kidney disease (4C) study: objectives, design, and methodology. Clin J Am Soc Nephrol. (2010) 5:1642-8. doi: 10.2215/CJN.08791209

31. Chen D, Cao G, Chen H, Argyopoulos CP, Yu H, Su W, et al. Identification of serum metabolites associating with chronic kidney disease progression and anti-fibrotic effect of 5-methoxytryptophan. Nat Commun. (2019) 10:1476. doi: 10.1038/s41467-019-09329-0

32. Maslowski KM, Vieira AT, Ng A, Kranich J, Sierro F, Yu D, et al. Regulation of inflammatory responses by gut microbiota and chemoattractant receptor GPR43. Nature. (2009) 461:1282-6. doi: 10.1038/nature08530

33. Sun C, Lin C, Pan H, Lee C, Lu S, Hsieh Y, et al. Clinical association between the metabolite of healthy gut microbiota, 3-indolepropionic acid and chronic kidney disease. Clin Nutr. (2019) 38:2945-8. doi: 10.1016/j.clnu.2018.11.029

34. Borges NA, Stenvinkel P, Bergman P, Qureshi AR, Lindholm B, Moraes $\mathrm{C}$, et al. Effects of probiotic supplementation on trimethylamine- $\mathrm{N}$-oxide plasma levels in hemodialysis patients: a pilot study. Probiotics Antimicrob Proteins. (2019) 11:648-54. doi: 10.1007/s12602-018-9411-1

35. Kieffer DA, Piccolo BD, Vaziri ND, Liu S, Lau WL, Khazaeli M, et al. Resistant starch alters gut microbiome and metabolomic profiles concurrent with amelioration of chronic kidney disease in rats. Am J Physiol Renal Physiol. (2016) 310:857. doi: 10.1152/ajprenal.00513.2015

36. Sun G, Yin Z, Liu N, Bian $X, Y u$ R, Su X, et al. Gut microbial metabolite TMAO contributes to renal dysfunction in a mouse model of diet-induced obesity. Biochem Biophys Res Commun. (2017) 493:96470. doi: 10.1016/j.bbrc.2017.09.108

37. Modena BD, Milam R, Harrison F, Cheeseman JA, Abecassis MM, Friedewald JJ, et al. Changes in urinary microbiome populations correlate in kidney transplants with interstitial fibrosis and tubular atrophy documented in early surveillance biopsies. Am J Transplant. (2017) 17:71223. doi: $10.1111 /$ ajt. 14038

38. Païssé S, Valle C, Servant F, Courtney M, Burcelin R, Amar J, et al. Comprehensive description of blood microbiome from healthy donors assessed by $16 \mathrm{~S}$ targeted metagenomic sequencing. Transfusion. (2016) 56:1138-47. doi: 10.1111/trf.13477

39. Wang X, Yang S, Li S, Zhao L, Hao Y, Qin J, et al. Aberrant gut microbiota alters host metabolome and impacts renal failure in humans and rodents. Gut. (2020). doi: 10.1136/gutjnl-2019-319766

40. Ma X, Wang Y, Wu H, Li F, Feng X, Xie Y, et al. Periodontal health relatedinflammatory and metabolic profiles of patients with end-stage renal disease: potential strategy for predictive, preventive, and personalized medicine. EPMA. (2021)12:1-12. doi: 10.1007/s13167-021-00239-0

41. Ebert T, Painer J, Bergman P, Qureshi AR, Giroud S, Stalder G, et al. Insights in the regulation of trimetylamine $\mathrm{N}$-oxide production using a comparative biomimetic approach suggest a metabolic switch in hibernating bears. Sci Rep. (2020) 10:20323. doi: 10.1038/s41598-020-76346-1

42. Kim JE, Kim H, Park JI, Cho H, Kwak M, Kim B, et al. The Association between Gut Microbiota and Uremia of Chronic Kidney Disease. Microorganisms. (2020) 8. doi: 10.3390/microorganisms 8060907

43. Zhu B, Shen J, Jiang R, Jin L, Zhan G, Liu J, et al. Abnormalities in gut microbiota and serum metabolites in hemodialysis patients with mild cognitive decline: a single-center observational study. Psychopharmacology. (2020) 237:2739-52. doi: 10.1007/s00213-020-05569-x

44. Wu I-W, Gao S-S, Chou H-C, Yang H-Y, Chang L-C, Kuo Y-L, et al. Integrative metagenomic and metabolomic analyses reveal severity-specific signatures of gut microbiota in chronic kidney disease. Theranostics. (2020) 10:5398-411. doi: 10.7150/thno.41725

45. Hsu C, Lu P, Hou C, Tain Y. Blood pressure abnormalities associated with gut microbiota-derived short chain fatty acids in children with congenital anomalies of the kidney and urinary tract. J Clin Med. (2019) 8:1090. doi: $10.3390 / \mathrm{jcm} 8081090$

46. El-Deeb OS, Atef MM, Hafez YM. The interplay between microbiotadependent metabolite trimethylamine $\mathrm{N}$-oxide, transforming growth factor $\beta / S M A D$ signaling and inflammasome activation in chronic kidney disease patients: a new mechanistic perspective. J Cell Biochem. (2019) 120:1447685. doi: $10.1002 /$ jcb. 28707

47. Hsu C, Lu P, Lo M, Lin I-, Chang-Chien G, Lin S, et al. Gut microbiotadependent trimethylamine $\mathrm{N}$-Oxide pathway associated with cardiovascular risk in children with early-stage chronic kidney disease. Int J Mol Sci. (2018) 19:3699. doi: 10.3390/ijms19123699

48. Gruppen EG, Garcia E, Connelly MA, Jeyarajah EJ, Otvos JD, Bakker SJL, et al. TMAO is associated with mortality: impact of modestly impaired renal function. Sci Rep. (2017) 7:13781. doi: 10.1038/s41598-017-13739-9

49. Ottiger M, Nickler M, Steuer C, Odermatt J, Huber A, Christ-Crain $\mathrm{M}$, et al. Trimethylamine-N-oxide (TMAO) predicts fatal outcomes in community-acquired pneumonia patients without evident coronary artery disease. Eur J Intern Med. (2016) 36:67-73. doi: 10.1016/j.ejim.2016. 08.017

50. Poesen R, Claes K, Evenepoel P, de Loor H, Augustijns P, Kuypers D, et al. Microbiota-derived phenylacetylglutamine associates with overall mortality and cardiovascular disease in patients with CKD. J Am Soc Nephrol. (2016) 27:3479-87. doi: 10.1681/ASN.2015121302

51. Poesen R, Evenepoel P, de Loor H, Bammens B, Claes K, Sprangers $\mathrm{B}$, et al. The influence of renal transplantation on retained 
microbial-human co-metabolites. Nephrol Dial Transplant. 31:1721-9. doi: 10.1093/ndt/gfw009

52. Mafune A, Iwamoto T, Tsutsumi Y, Nakashima A, Yamamoto I, Yokoyama $\mathrm{K}$, et al. Associations among serum trimethylamine- $\mathrm{N}$-oxide (TMAO) levels, kidney function and infarcted coronary artery number in patients undergoing cardiovascular surgery: a cross-sectional study. Clin Exp Nephrol. (2016) 20:731-9. doi: 10.1007/s10157-015-1207-y

53. Poesen R, Windey K, Neven E, Kuypers D, De Preter V, Augustijns P, et al. The influence of CKD on colonic microbial metabolism. J Am Soc Nephrol. (2016) 27:1389-99. doi: 10.1681/ASN.2015030279

54. Tang WHW, Wang Z, Kennedy DJ, Wu Y, Buffa JA, Agatisa-Boyle $\mathrm{B}$, et al. Gut microbiota-dependent trimethylamine N-oxide (TMAO) pathway contributes to both development of renal insufficiency and mortality risk in chronic kidney disease. Circ Res. (2015) 116:44855. doi: 10.1161/CIRCRESAHA.116.305360

55. Wikoff WR, Nagle MA, Kouznetsova VL, Tsigelny IF, Nigam SK. Untargeted metabolomics identifies enterobiome metabolites and putative uremic toxins as substrates of organic anion transporter 1 (Oat1). J Proteome Res. (2011) 10:2842-51. doi: 10.1021/pr200093w

56. Sun C, Li J, Wang Y, Lin S, Ou Y, Lin C, et al. Indoxyl sulfate caused behavioral abnormality and neurodegeneration in mice with unilateral nephrectomy. Aging. (2021) 13:6681-701. doi: 10.18632/aging.202523

57. Hu X, Xie Y, Xiao Y, Zeng W, Gong Z, Du J. Longitudinal analysis of fecal microbiome and metabolome during renal fibrotic progression in a unilateral ureteral obstruction animal model. Eur J Pharmacol. (2020) 886:173555. doi: 10.1016/j.ejphar.2020.173555

58. Hsu C, Yang H, Hou C, Chang-Chien G, Lin S, Tain Y. Maternal adenineinduced chronic kidney disease programs hypertension in adult male rat offspring: implications of nitric oxide and gut microbiome derived metabolites. Int J Mol Sci. (2020) 21:7237. doi: 10.3390/ijms21197237

59. Mishima E, Ichijo M, Kawabe T, Kikuchi K, Akiyama Y, Toyohara $\mathrm{T}$, et al. Germ-free conditions modulate host purine metabolism, exacerbating adenine-induced kidney damage. Toxins. (2020) 12:547. doi: $10.3390 /$ toxins 12090547

60. Bush KT, Singh P, Nigam SK. Gut-derived uremic toxin handling in vivo requires OAT-mediated tubular secretion in chronic kidney disease. JCI Insight. (2020) 5:e133817. doi: 10.1172/jci.insight.133817

61. Feng Y, Cao G, Chen D, Vaziri ND, Chen L, Zhang J, et al. Microbiomemetabolomics reveals gut microbiota associated with glycine-conjugated metabolites and polyamine metabolism in chronic kidney disease. Cell Mol Life Sci. (2019) 76:4961-78. doi: 10.1007/s00018-019-03155-9

62. Chen L, Chen D, Liu J, Zhang J, Vaziri ND, Zhuang S, et al. Unilateral ureteral obstruction causes gut microbial dysbiosis and metabolome disorders contributing to tubulointerstitial fibrosis. Exp Mol Med. (2019) 51:118. doi: 10.1038/s12276-019-0234-2

63. Tao J, Zhao M, Jiang S, Pu X, Wei X. Comparative metabolism of two major compounds in Fructus Corni extracts by gut microflora from normal and chronic nephropathy rats in vitro by UPLC-Q-TOF/MS. J Chromatogr B Analyt Technol Biomed Life Sci. (2018) 1073:1706. doi: 10.1016/j.jchromb.2017.12.025

64. Du L, Tao J, Jiang S, Qian D, Guo J, Duan J. Metabolic profiles of the flos abelmoschus manihot extract by intestinal bacteria from the normal and CKD model rats based on UPLC-Q-TOF/MS. Biomed Chromatogr. (2017) 31:e3795. doi: 10.1002/bmc.3795

65. Meinardi S, Jin K, Barletta B, Blake DR, Vaziri ND. Exhaled breath and fecal volatile organic biomarkers of chronic kidney disease. Biochim Biophys Acta. (2013) 1830:2531-7. doi: 10.1016/j.bbagen.2012.12.006

66. Chaves LD, Abyad S, Honan AM, Bryniarski MA, McSkimming DI, Stahura CM, et al. Unconjugated p-cresol activates macrophage macropinocytosis leading to increased LDL uptake. JCI Insight. (2021) 6:e144410. doi: 10.1172/jci.insight.144410

67. Zhang Z, Yang L, Wan Y, Liu C, Jiang S, Shang E, et al. Integrated gut microbiota and fecal metabolomics reveal the renoprotective effect of rehmanniae radix preparata and corni fructus on adenine-induced CKD rats. J Chromatogr B Analyt Technol Biomed Life Sci. (2021) 1174:122728. doi: 10.1016/j.jchromb.2021.122728

68. Liu Y, Li YJ, Loh YW, Singer J, Zhu W, Macia L, et al. Fiber derived microbial metabolites prevent acute kidney injury through G-Protein coupled receptors and HDAC inhibition. Front Cell Dev Biol. (2021) 9:648639. doi: 10.3389/fcell.2021.648639

69. de Andrade LS, Sardá FAH, Pereira NBF, Teixeira RR, Rodrigues SD, de Lima JD, et al. Effect of unripe banana flour on gut-derived uremic toxins in individuals undergoing peritoneal dialysis: a randomized, double-blind, placebo-controlled, crossover trial. Nutrients. (2021) 13:646. doi: $10.3390 /$ nu13020646

70. Zhang W, Miikeda A, Zuckerman J, Jia X, Charugundla S, Zhou $Z$, et al. Inhibition of microbiota-dependent TMAO production attenuates chronic kidney disease in mice. Sci Rep. (2021) 11:518. doi: 10.1038/s41598-020-80063-0

71. Hsu C, Hou C, Chang-Chien G, Lin S, Yang H, Tain Y. Perinatal resveratrol therapy prevents hypertension programmed by maternal chronic kidney disease in adult male offspring: implications of the gut microbiome and their metabolites. Biomedicines. (2020) 8:567. doi: 10.3390/biomedicines8120567

72. Karaduta O, Glazko G, Dvanajscak Z, Arthur J, Mackintosh S, Orr L, et al. Resistant starch slows the progression of CKD in the 5/6 nephrectomy mouse model. Physiol Rep. (2020) 8:e14610. doi: 10.14814/phy2.14610

73. Wu I-W, Lee C-C, Hsu H-J, Sun C-Y, Chen Y-C, Yang K-J, et al. Compositional and functional adaptations of intestinal microbiota and related metabolites in CKD patients receiving dietary protein restriction. Nutrients. (2020) 12:2799. doi: 10.3390/nu12092799

74. Ephraim E, Jewell DE. Effect of added dietary betaine and soluble fiber on metabolites and fecal microbiome in dogs with early renal disease. Metabolites. (2020) 10:370. doi: 10.3390/metabo10090370

75. Nagayama Y, Isoo N, Nakashima A, Suzuki K, Yamano M, Nariyama T, et al. Renoprotective effects of paramylon, a $\beta-1,3-\mathrm{D}$-Glucan isolated from Euglena gracilis $\mathrm{Z}$ in a rodent model of chronic kidney disease. PLoS ONE. (2020) 15:e0237086. doi: 10.1371/journal.pone.0237086

76. Hall JA, Jackson MI, Jewell DE, Ephraim E. Chronic kidney disease in cats alters response of the plasma metabolome and fecal microbiome to dietary fiber. PLoS ONE. (2020) 15:e0235480. doi: 10.1371/journal.pone.0235480

77. Hsu C-N, Lin I-C, Yu H-R, Huang L-T, Tiao M-M, Tain Y-L. Maternal tryptophan supplementation protects adult rat offspring against hypertension programmed by maternal chronic kidney disease: implication of tryptophan-metabolizing microbiome and aryl hydrocarbon receptor. Int J Mol Sci. (2020) 21:4552. doi: 10.3390/ijms21124552

78. Sato E, Hosomi K, Sekimoto A, Mishima E, Oe Y, Saigusa D, et al. Effects of the oral adsorbent AST-120 on fecal p-cresol and indole levels and on the gut microbiota composition. Biochem Biophys Res Commun. (2020) 525:773-9. doi: 10.1016/j.bbrc.2020.02.141

79. Gupta N, Buffa JA, Roberts AB, Sangwan N, Skye SM, Li L, et al. Targeted inhibition of gut microbial trimethylamine $\mathrm{N}$-Oxide production reduces renal tubulointerstitial fibrosis and functional impairment in a murine model of chronic kidney disease. Arterioscler Thromb Vasc Biol. (2020) 40:123955. doi: 10.1161/ATVBAHA.120.314139

80. Cai H, Su S, Li Y, Zhu Z, Guo J, Zhu Y, et al. Danshen can interact with intestinal bacteria from normal and chronic renal failure rats. Biomed Pharmacother. (2019) 109:1758-71. doi: 10.1016/j.biopha.2018.11.047

81. $\mathrm{Li} \mathrm{T}$, Gua $\mathrm{C}, \mathrm{Wu} \mathrm{B}$, Chen $\mathrm{Y}$. Increased circulating trimethylamine $\mathrm{N}$-oxide contributes to endothelial dysfunction in a rat model of chronic kidney disease. Biochem Biophys Res Commun. (2018) 495:20717. doi: 10.1016/j.bbrc.2017.12.069

82. Kikuchi M, Ueno M, Itoh Y, Suda W, Hattori M. Uremic toxin-producing gut microbiota in rats with chronic kidney disease. Nephron. (2017) 135:5160. doi: 10.1159/000450619

83. Wu B, Jiang $\mathrm{H}, \mathrm{He} \mathrm{Q}$, Wang $\mathrm{M}$, Xue J, Liu $\mathrm{H}$, et al. Liquid chromatography/mass spectrometry reveals the effect of lactobacillus treatment on the faecal metabolite profile of rats with chronic renal failure. Nephron. (2017) 135:156-66. doi: 10.1159/0004 52453

84. Poesen R, Evenepoel P, de Loor H, Delcour JA, Courtin CM, Kuypers $\mathrm{D}$, et al. The influence of prebiotic arabinoxylan oligosaccharides on microbiota derived uremic retention solutes in patients with chronic kidney disease: a randomized controlled trial. PLoS ONE. (2016) 11:e0153893. doi: 10.1371/journal.pone.0153893

85. Stevens PE, Levin A. Evaluation and management of chronic kidney disease: synopsis of the kidney disease: improving global outcomes 
2012 clinical practice guideline. Ann Intern Med. (2013) 158:82530. doi: 10.7326/0003-4819-158-11-201306040-00007

86. Hodgkins KS, Schnaper HW. Tubulointerstitial injury and the progression of chronic kidney disease. Pediatr Nephrol. (2012) 27:901-9. doi: 10.1007/s00467-011-1992-9

87. Vanholder R, Van Laecke S, Glorieux G, Verbeke F, Castillo-Rodriguez E, Ortiz A. Deleting death and dialysis: conservative care of cardio-vascular risk and kidney function loss in chronic kidney disease (CKD). Toxins. (2018) 10:237. doi: 10.3390/toxins10060237

88. Rapa SF, Di Iorio BR, Campiglia P, Heidland A, Marzocco S. Inflammation and oxidative stress in chronic kidney disease-potential therapeutic role of minerals, vitamins and plant-derived metabolites. Int J Mol Sci. (2019) 21:263. doi: $10.3390 /$ ijms 21010263

89. Crespo-Salgado J, Vehaskari VM, Stewart T, Ferris M, Zhang Q, Wang $\mathrm{G}$, et al. Intestinal microbiota in pediatric patients with end stage renal disease: a midwest pediatric nephrology consortium study. Microbiome. (2016) 4:50. doi: 10.1186/s40168-016-0195-9

90. Yang T, Richards EM, Pepine CJ, Raizada MK. The gut microbiota and the brain-gut-kidney axis in hypertension and chronic kidney disease. Nat Rev Nephrol. (2018) 14:442-56. doi: 10.1038/s41581-018-0018-2

91. Andrade-Oliveira V, Foresto-Neto O, Watanabe IKM, Zatz R, Câmara NOS. Inflammation in renal diseases: new and old players. Front Pharmacol. (2019) 10:1192. doi: 10.3389/fphar.2019.01192

92. Mihai S, Codrici E, Popescu ID, Enciu A, Albulescu L, Necula LG, et al. Inflammation-related mechanisms in chronic kidney disease prediction, progression, and outcome. J Immunol Res. (2018) 2018:2180373. doi: $10.1155 / 2018 / 2180373$

93. Velmurugan G, Dinakaran V, Rajendhran J, Swaminathan $K$. Blood microbiota and circulating microbial metabolites in diabetes and cardiovascular disease. Trends Endocrinol Metab. (2020) 31:835-47. doi: 10.1016/j.tem.2020.01.013

94. Schiffrin EL. How structure, mechanics, and function of the vasculature contribute to blood pressure elevation in hypertension. Can J Cardiol. (2020) 36:648-58. doi: 10.1016/j.cjca.2020.02.003

95. Relman DA. Microbiota: a high-pressure situation for bacteria. Nature. (2017) 551:571-2. doi: 10.1038/nature24760

96. Wilck N, Matus MG, Kearney SM, Olesen SW, Forslund K, Bartolomaeus $\mathrm{H}$, et al. Salt-responsive gut commensal modulates TH17 axis and disease. Nature. (2017) 551:585-9. doi: 10.1038/nature24628

97. Ghosh TS, Arnoux J, O'Toole PW. Metagenomic analysis reveals distinct patterns of gut lactobacillus prevalence, abundance, and geographical variation in health and disease. Gut Microbes. (2020) 12:1-19. doi: 10.1080/19490976.2020.1822729

98. Rossi M, Johnson DW, Morrison M, Pascoe EM, Coombes JS, Forbes JM, et al. Synbiotics easing renal failure by improving gut microbiology (SYNERGY): a randomized trial. Clin J Am Soc Nephrol. (2016) 11:22331. doi: 10.2215/CJN.05240515

99. Cruz-Mora J, Martínez-Hernández NE, Martín del Campo-López F, Viramontes-Hörner D, Vizmanos-Lamotte B, Muñoz-Valle JF, et al. Effects of a symbiotic on gut microbiota in Mexican patients with end-stage renal disease. J Ren Nutr. (2014) 24:330-5. doi: 10.1053/j.jrn.2014.05.006

100. Guida B, Germanò R, Trio R, Russo D, Memoli B, Grumetto L, et al. Effect of short-term synbiotic treatment on plasma p-cresol levels in patients with chronic renal failure: a randomized clinical trial. Nutr Metab Cardiovasc Dis. (2014) 24:1043-9. doi: 10.1016/j.numecd.2014.04.007

101. Lopes RCSO, Balbino KP, Jorge MDP, Ribeiro AQ, Martino HSD, Alfenas RCG. Modulation of intestinal microbiota, control of nitrogen products and inflammation by pre/probiotics in chronic kidney disease: a systematic review. Nutr Hosp. (2018) 35:722-30. doi: 10.20960/nh.1642

102. Fernandez-Prado R, Esteras R, Perez-Gomez MV, Gracia-Iguacel C, Gonzalez-Parra E, Sanz AB, et al. Nutrients turned into toxins: microbiota modulation of nutrient properties in chronic kidney disease. Nutrients. (2017) 9:489. doi: 10.3390/nu9050489

103. Mafra D, Borges N, Alvarenga L, Esgalhado M, Cardozo L, Lindholm B, et al. Dietary components that may influence the disturbed gut microbiota in chronic kidney disease. Nutrients. (2019) 11:496. doi: 10.3390/nu11030496

104. Ramezani A, Raj DS. The gut microbiome, kidney disease, and targeted interventions. J Am Soc Nephrol. (2014) 25:657-70. doi: 10.1681/ASN. 2013080905
105. Lu L, Huang Y, Wang M, Chen D, Wan H, Wei L, et al. Dietary fiber intake is associated with chronic kidney disease (CKD) progression and cardiovascular risk, but not protein nutritional status, in adults with CKD. Asia Pac J Clin Nutr. (2017) 26:598-605. doi: 10.6133/apjen. 072016.08

106. Camerotto C, Cupisti A, D’Alessandro C, Muzio F, Gallieni M. Dietary fiber and gut microbiota in renal diets. Nutrients. (2019) 1:2149. doi: 10.3390/nu1 1092149

107. Esgalhado M, Kemp JA, Azevedo R, Paiva BR, Stockler-Pinto MB, Dolenga $\mathrm{CJ}$, et al. Could resistant starch supplementation improve inflammatory and oxidative stress biomarkers and uremic toxins levels in hemodialysis patients? a pilot randomized controlled trial. Food Funct. (2018) 9:650816. doi: $10.1039 / \mathrm{C} 8 \mathrm{FO} 01876 \mathrm{~F}$

108. Tayebi-Khosroshahi H, Habibzadeh A, Niknafs B, Ghotaslou R, Yeganeh Sefidan F, Ghojazadeh M, et al. The effect of lactulose supplementation on fecal microflora of patients with chronic kidney disease; a randomized clinical trial. J Renal Inj Prev. (2016) 5:162-7. doi: 10.15171/jrip. 2016.34

109. Whiteside SA, Razvi H, Dave S, Reid G, Burton JP. The microbiome of the urinary tract-a role beyond infection. Nat Rev Urol. (2015) 12:8190. doi: 10.1038/nrurol.2014.361

110. Morand A, Cornu F, Dufour J, Tsimaratos M, Lagier J, Raoult D. Human bacterial repertoire of the urinary tract: a potential paradigm shift. J Clin Microbiol. (2019) 57:675. doi: 10.1128/JCM.00675-18

111. Gerges-Knafl D, Pichler P, Zimprich A, Hotzy C, Barousch W, Lang RM, et al. The urinary microbiome shows different bacterial genera in renal transplant recipients and non-transplant patients at time of acute kidney injury - a pilot study. BMC Nephrol. (2020) 21:117. doi: 10.1186/s12882-020-01773-1

112. Rani A, Ranjan R, McGee HS, Andropolis KE, Panchal DV, Hajjiri $Z$, et al. Urinary microbiome of kidney transplant patients reveals dysbiosis with potential for antibiotic resistance. Transl Res. (2017) 181:5970. doi: 10.1016/j.trsl.2016.08.008

113. Wu JF, Muthusamy A, Al-Ghalith GA, Knights D, Guo B, Wu $B$, et al. Urinary microbiome associated with chronic allograft dysfunction in kidney transplant recipients. Clin Transplant. (2018) 32:e13436. doi: 10.1111/ctr.13436

114. Schreiber PW, Kufner V, Hübel K, Schmutz S, Zagordi O, Kaur A, et al. Metagenomic Virome sequencing in living donor and recipient kidney transplant pairs revealed JC polyomavirus transmission. Clin Infect Dis. (2019) 69:987-94. doi: 10.1093/cid/ciy1018

115. Kramer H, Kuffel G, Thomas-White K, Wolfe AJ, Vellanki K, Leehey DJ, et al. Diversity of the midstream urine microbiome in adults with chronic kidney disease. Int Urol Nephrol. (2018) 50:1123-30. doi: 10.1007/s11255-018-1860-7

116. Wilmanski T, Rappaport N, Earls JC, Magis AT, Manor O, Lovejoy J, et al. Blood metabolome predicts gut microbiome $\alpha$-diversity in humans. Nat Biotechnol. (2019) 37:1217-28. doi: 10.1038/s41587-019-0233-9

117. Shah NB, Allegretti AS, Nigwekar SU, Kalim S, Zhao S, Lelouvier B, et al. Blood microbiome profile in CKD: a pilot study. Clin J Am Soc Nephrol. (2019) 14:692-701. doi: 10.2215/CJN.12161018

Conflict of Interest: The authors declare that the research was conducted in the absence of any commercial or financial relationships that could be construed as a potential conflict of interest.

Publisher's Note: All claims expressed in this article are solely those of the authors and do not necessarily represent those of their affiliated organizations, or those of the publisher, the editors and the reviewers. Any product that may be evaluated in this article, or claim that may be made by its manufacturer, is not guaranteed or endorsed by the publisher.

Copyright $\odot 2022$ Wehedy, Shatat and Al Khodor. This is an open-access article distributed under the terms of the Creative Commons Attribution License (CC BY). The use, distribution or reproduction in other forums is permitted, provided the original author(s) and the copyright owner(s) are credited and that the original publication in this journal is cited, in accordance with accepted academic practice. No use, distribution or reproduction is permitted which does not comply with these terms. 